\title{
Therapeutic Potential of Targeting the SUMO Pathway in Cancer
}

\author{
Antti Kukkula ${ }^{1}$, Veera K. Ojala ${ }^{1,2,3,4}$, Lourdes M. Mendez ${ }^{5}$, Lea Sistonen ${ }^{4,6}$, Klaus Elenius ${ }^{1,3,4,7}$ (D) \\ and Maria Sundvall 1,7,*
}

check for updates

Citation: Kukkula, A.; Ojala, V.K.;

Mendez, L.M.; Sistonen, L.; Elenius, K.; Sundvall, M. Therapeutic Potential of Targeting the SUMO Pathway in Cancer. Cancers 2021, 13, 4402. https://doi.org/10.3390/ cancers 13174402

Academic Editor: Tarek Abbas

Received: 5 August 2021

Accepted: 26 August 2021

Published: 31 August 2021

Publisher's Note: MDPI stays neutral with regard to jurisdictional claims in published maps and institutional affiliations.

Copyright: (c) 2021 by the authors. Licensee MDPI, Basel, Switzerland. This article is an open access article distributed under the terms and conditions of the Creative Commons Attribution (CC BY) license (https:// creativecommons.org/licenses/by/ $4.0 /)$.
1 Cancer Research Unit, FICAN West Cancer Center Laboratory, Institute of Biomedicine, Turku University Hospital, University of Turku, FI-20520 Turku, Finland; antti.v.kukkula@utu.fi (A.K.); vekaoj@utu.fi (V.K.O.); klaele@utu.fi (K.E.)

2 Turku Doctoral Programme of Molecular Medicine, University of Turku, FI-20520 Turku, Finland

3 Medicity Research Laboratories, University of Turku, FI-20520 Turku, Finland

4 Turku Bioscience Centre, University of Turku and Åbo Akademi University, FI-20520 Turku, Finland; lea.sistonen@abo.fi

5 Beth Israel Deaconess Cancer Center, Beth Israel Deaconess Medical Center, Department of Medicine and Pathology, Cancer Research Institute, Harvard Medical School, Boston, MA 02115, USA; lmendez@bidmc.harvard.edu

6 Faculty of Science and Engineering, Cell Biology, Åbo Akademi University, FI-20520 Turku, Finland

7 Department of Oncology, Turku University Hospital, FI-20521 Turku, Finland

* Correspondence: mahesu@utu.fi

Simple Summary: The small ubiquitin-like modifier (SUMO) pathway regulates the hallmark properties of cancer cells. Moreover, alterations in activity and in levels of SUMO machinery components have been observed in human cancer. Due to the reversible nature of this post-translational protein modification, the balance between SUMOylation and the removal of SUMO is critical. Early-phase clinical trials are currently evaluating the safety and efficacy of SUMO pathway inhibition in cancer patients. In this comprehensive review, we critically discuss the potential of targeting the SUMO pathway as a therapeutic option for cancer.

Abstract: SUMOylation is a dynamic and reversible post-translational modification, characterized more than 20 years ago, that regulates protein function at multiple levels. Key oncoproteins and tumor suppressors are SUMO substrates. In addition to alterations in SUMO pathway activity due to conditions typically present in cancer, such as hypoxia, the SUMO machinery components are deregulated at the genomic level in cancer. The delicate balance between SUMOylation and deSUMOylation is regulated by SENP enzymes possessing SUMO-deconjugation activity. Dysregulation of SUMO machinery components can disrupt the balance of SUMOylation, contributing to the tumorigenesis and drug resistance of various cancers in a context-dependent manner. Many molecular mechanisms relevant to the pathogenesis of specific cancers involve SUMO, highlighting the potential relevance of SUMO machinery components as therapeutic targets. Recent advances in the development of inhibitors targeting SUMOylation and deSUMOylation permit evaluation of the therapeutic potential of targeting the SUMO pathway in cancer. Finally, the first drug inhibiting SUMO pathway, TAK-981, is currently also being evaluated in clinical trials in cancer patients. Intriguingly, the inhibition of SUMOylation may also have the potential to activate the anti-tumor immune response. Here, we comprehensively and systematically review the recent developments in understanding the role of SUMOylation in cancer and specifically focus on elaborating the scientific rationale of targeting the SUMO pathway in different cancers.

Keywords: cancer; post-translational modification (PTM); small ubiquitin-like modifier (SUMO); protein inhibitor of activated STAT (PIAS); sentrin-specific protease (SENP) 


\section{Introduction}

Cancer is consistently ranked among the leading causes of death worldwide [1]. Hallmarks of cancer cells include uncontrolled proliferation, inhibition of apoptosis and differentiation, immune evasion, and the potential to metastasize [2]. Cellular homeostasis and responses to various stimuli are regulated by a wide array of post-translational modifications (PTM), including phosphorylation, acetylation, hydroxylation, glycosylation, and methylation as well as small protein modifications, such as ubiquitination [3,4]. Dysregulation of PTMs is frequent in cancer and plays a significant role in the pathogenesis of the disease [5,6]. Ubiquitination and its analogous modifications neddylation and SUMOylation are increasingly viewed as key regulators of tumorigenesis of various cancers [7-9]. In this review, we discuss SUMOylation's contribution to the malignant phenotype and the pathway's role as a potential therapeutic target in cancers originating from different cell types and organs.

\section{Basic Principles of SUMOylation and Its Role in Physiology}

Small ubiquitin-like modifiers (SUMOs) are a group of ubiquitin-like small proteins that are attached to substrate proteins in a reversible post-translational modification termed SUMOylation that is highly conserved in eukaryotes $[9,10]$. The SUMO pathway is involved in several central cellular processes. Modification by SUMO mediates the protein-protein interactions of target substrates, and influences their subcellular localization, stability, and enzymatic function $[9,11]$. SUMOylation can simultaneously target several members of a protein group to modulate the activity of a specific pathway [12]. The SUMO pathway shares some structural and functional similarities with the ubiquitin pathway [11]. The global molecular structure of SUMO is similar to ubiquitin, and both have a $\beta \beta \alpha \beta \beta \alpha \beta$ fold structure and a conserved position of a diglycine (GG) motif required for isopeptide bond formation $[13,14]$.

To date, five isoforms of SUMO (SUMO1, 2, 3, 4, and 5) have been identified in the human genome [9]. SUMO1, SUMO2, and SUMO3 are ubiquitously expressed in tissues, while the expression of SUMO4 and SUMO5 is restricted only to specific tissues [9,15-18]. SUMO1, SUMO2, and SUMO3 account for most of SUMO modifications, whereas the functional roles of SUMO4 and SUMO5 are more unclear [15,18]. SUMO2 and SUMO3 both share $97 \%$ sequence identity, but share only 50\% sequence similarity with SUMO1 [19]. Expression levels of SUMOs are dynamic and fluctuate between different developmental stages [17]. SUMOs can be covalently attached to a single lysine residue (monoSUMOylation) or to multiple lysine residues (multiSUMOylation) of the substrate (Figure 1). SUMO is preferentially attached to SUMO consensus $\Psi$ KxE motifs of substrates, in which $\Psi$ denotes a hydrophobic amino acid, $\mathrm{K}$ is lysine, $\mathrm{x}$ is any amino acid and $\mathrm{E}$ is glutamic acid, although some substrates are also SUMOylated at lysines in non-consensus sites $[10,20,21]$. SUMO itself may also be SUMOylated (polySUMOylation) to form polymeric SUMO chains, which are restricted to SUMO2 and SUMO3 [22]. SUMO1 does not form chains efficiently and is predominantly associated with monoSUMOylation [22]. However, SUMO1 can be attached to SUMO2/3 chains, resulting in the termination of chain elongation [23]. Non-covalent attachment of SUMO is regulated through the SUMO interaction motif (SIM) of binding partners $[24,25]$.

The enzymatic cascade regulating SUMOylation comprises SUMO E1-activating, E2-conjugating, E3 ligase and deconjugating enzymes (Figure 1) [9]. Maturation and deconjugation (deSUMOylation) of SUMO is regulated by the family of cysteine proteases, sentrin-specific proteases (SENP1, 2, 3, 5, 6, 7, and 8) [26]. SENP1-7 have specific, varying subcellular localizations and regulate SUMO processing, whereas SENP8 displays substrate specificity only for ubiquitin-like protein NEDD8 [26-28]. SUMO E1-activating enzyme (SAE1/2) activates mature SUMO and transfers it to the only known mammalian E2-conjugating enzyme, Ubc9 (encoded by UBE2I) [29-31]. Ubc9 alone is capable of conjugating SUMO to substrates in vitro. However, E3 ligase enzymes are required for specificity and efficiency of SUMOylation. The family of protein inhibitors of activated STAT (PIAS) 
is the major class of SUMO E3 ligases, and the human genome has four PIAS genes (PIAS1, 2,3 , and 4 ) that encode seven protein products, PIAS1, PIAS2a (PIASx $\alpha$ ), PIAS2b (PIASx $\beta$ ), PIAS3, PIAS3L, PIAS4 (PIASy), and PIASyE6- [32,33]. Other classes of SUMO E3 ligases include the well-characterized Ran-binding protein 2 (RanBP2), and few other E3 ligases, such as ZNF451, polycomb protein PC2 (also known as CBX4), and some members of the tripartite motif (TRIM) protein family [34-38].

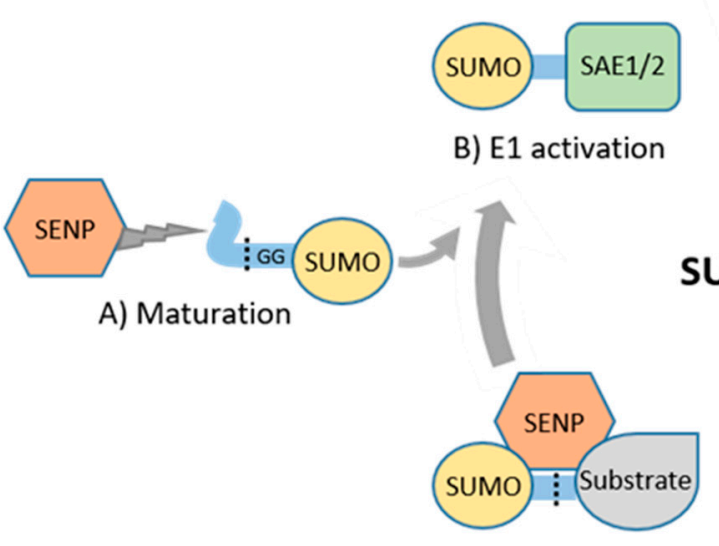

E) Deconjugation

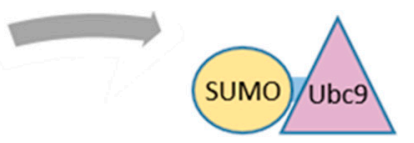

C) E2 conjugation

SUMO cycle

Figure 1. The enzymatic SUMO cascade. (A) SENPs cleave off amino acids from precursor SUMO to produce a mature SUMO. (B) SAE1/SAE2 forms of a thioester bond between SUMO'S GG and catalytic cysteine residue of SAE1/2. (C) Thioester bond is formed between SUMO's GG and catalytic cysteine residue of Ubc9. (D) Ubc9 catalyzes formation of an isopeptide bond between GG and target substrate's lysine residue often with assistance of an E3 ligase. (E) SENPs deconjugate SUMO from the substrate.

The SUMO pathway undergoes constant cross talk with other post-translational modifications, including phosphorylation and methylation [39-41]. For instance, phosphorylation can influence SUMOylation of substrates containing the conserved phosphorylationdependent SUMOylation motif (PDSM), which mediates phosphorylation-dependent SUMOylation of various transcriptional regulators [39]. In addition, lysine methylation of the KKxE motif can create a motif resembling the SUMO consensus site in substrates containing the KKxE motif [40]. HMGA2 SUMOylation is dependent on its methylation at K66 and K67 of KKAE motif by methyltransferase SET7/9. The KKxE motif is present in several other proteins, including the polyhomeotic complex 1 (PHC1), which also requires methylation for its complete SUMOylation.

The importance of SUMOylation in physiology is apparent from early development. A functional SUMO pathway is essential for embryogenesis. Loss of Ubc9 leads to severe defects of chromosome condensation and segregation, as well as disruption of nuclear organization, resulting in death at early embryonic development in mice [42]. SUMO1 knockout mice are viable, as SUMO2/3 can compensate for most functions of SUMO1 [17,43]. Interestingly, $\mathrm{SUMO}^{-/-}$mice are also viable, but the knockout of SUMO2 leads to severe developmental defects and early death before adulthood, indicating that SUMO2 is essential for the development. Balance of SUMOylation and deSUMOylation is critical for embryonic development, as knockout of SENP1, SENP2, or SENP3 results in embryonic lethality in mice, suggesting non-redundancy and substrate specificity among SENPs [44-46]. SENP1 ${ }^{-1-}$ mice have severe fetal anemia and SENP2 ${ }^{-/-}$mice display defects in trophoblast development, whereas conditional knockout Senp $3^{+/-}$mice have impaired cytokine and inflammatory signaling. PIAS1 ${ }^{-/}$and PIAS4 ${ }^{-/-}$knockout mice are produced at a lower frequency than the expected Mendelian ratio due to increased perinatal lethality, and both knockouts display defects in cytokine signaling [47,48]. Surviving PIAS1 $^{-/-}$mice are runts compared to their wild-type counterparts, whereas PIAS4 ${ }^{-/-}$ 
mice show no obvious phenotype. PIAS2 ${ }^{-/-}$knockout mice have reduced testis weight and sperm count but remain viable and fertile [49]. PIAS3 ${ }^{-/}$mice are viable and show no overt phenotype but have an impaired visual response of medium wavelength cones [50].

\section{Altered Expression and Prognostic Significance of SUMO Pathway in Cancer}

Dysregulated mRNA and protein levels of the SUMO machinery components have been reported in tissue samples of cancer patients with potential prognostic associations (Table S1 and Table 1). In the majority of the published reports, the expression levels of SUMO pathway components are upregulated in cancer and are associated with a higher histological grade, higher stage, presence of metastases and poor prognosis. Interestingly, genome-wide analyses have identified concurrently increased levels of multiple SUMO machinery components in certain cancer types [51]. However, high expression has been associated with better prognosis in some cancer types. Downregulated expression levels in cancer tissues have consistently been reported for SENP2 [52-57] and PIAS2 [58-60]. The prognostic value of a single SUMO machinery component can also vary between cancer (sub)types, and, e.g., the value for PC2 [61,62] and PIAS4 [63,64] as prognostic biomarkers in breast cancer and for PIAS3 $[65,66]$ in mesothelioma remains ambiguous (Table 1). Bioinformatic analyses of the SUMO machinery protein and mRNA levels, and their association with prognosis, utilizing datasets from various databases are generally well in line with the other published analyses of often smaller sample sizes [67-69] (and Supplementary Table S1). Mass spectrometry-based methods might decrease variability in protein level analyses caused by the use of different antibodies, whereas IHC allows analysis of the subcellular localization of a protein, which might be crucial for the prognostic significance of the SUMO machinery components in particular [63,70,71].

\section{Regulation of SUMO Machinery Expression and Activity in Cancer}

Dysregulation of SUMO pathway components in cancer tissues is often detectable already at the mRNA level (Supplementary Table S1). The expression of SUMO machinery components can be epigenetically altered by DNA methylation. For instance, promoter hypomethylation of SENP6 induces expression of SENP6 in hepatocellular carcinoma (HCC) tissues, and elevated SENP6 mRNA and protein levels are associated with promotion of HCC tumorigenesis [72,73]. At the post-transcriptional level, numerous miRNAs are implicated in SUMO regulation, and inverse expression levels of SUMO components and their miRNA-regulators are found in several cancers [74-78]. For example, a low expression of miR-145 is correlated with high expression of SENP1 in prostate cancer cells, and introduction of miR-145 causes cell cycle arrest via inhibition of SENP1 [76]. Oncogenic miRNA-9 and miRNA-181a inhibit PIAS3 in IL-6 ${ }^{\text {high }}$ breast cancer to promote expansion of early-stage myeloid-derived suppressor cells, resulting in suppression of T-cell immunity [79].

Dysregulation of the expression of SUMO machinery components in protein level can also occur in cancer. Post-translational regulation by, e.g., ubiquitin and subsequent proteasomal degradation may be involved, resulting in alterations in expression levels in cancer $[80,81]$. Moreover, reactive oxygen species (ROS) typically present in cancer influence protein expression levels of SENPs [82,83]. For instance, the ROS-induced increase in SENP3 level can drive carcinogenesis of head and neck cancer via deSUMOylation and subsequent hyperphosphorylation of STAT3 [83].

In addition to changes in expression levels, catalytic activity of select SUMO pathway components can directly be regulated by conditions typical in cancer, such as hypoxia $[84,85]$. Hypoxia induces a rapid and reversible inhibition of catalytic activity of SENP1 and SENP3, resulting in altered SUMOylation of a subset of proteins, such as the co-repressor BHLHE40 that is implicated in metabolic reprogramming upon hypoxia. 
Table 1. Prognostic value of SUMO pathway components. More comprehensive list of studies with prognostic and expression data and all references are in Supplementary Table S1.

\begin{tabular}{|c|c|c|c|}
\hline \multicolumn{2}{|c|}{$\begin{array}{l}\text { High Expression Associates with } \\
\text { Poor Prognosis }\end{array}$} & \multicolumn{2}{|c|}{$\begin{array}{l}\text { High Expression Associates with } \\
\text { Good Prognosis }\end{array}$} \\
\hline Cancer Type & Protein(s) & Cancer Type & Protein(s) \\
\hline adrenocortical & $\begin{array}{c}\text { PIAS3, PIAS4, SAE1, SAE2, } \\
\text { SENP1, SENP3, SUMO1, } \\
\text { SUMO2, SUMO4 }\end{array}$ & bladder & Ubc9 \\
\hline breast & $\begin{array}{c}\text { PC2, PIAS3, PIAS4, SAE1, } \\
\text { SAE2, SENP5, SENP7L, } \\
\text { SUMO1, SUMO2, SUMO3, } \\
\text { Ubc9 }\end{array}$ & breast & PC2, PIAS1, PIAS4 \\
\hline colorectal & SAE2, SENP1, SUMO1 & cervical & PIAS3 \\
\hline gastric & $\begin{array}{l}\text { PC2, PIAS2, SAE2, SUMO3, } \\
\text { Ubc9 }\end{array}$ & colorectal & PC2 \\
\hline glioma & SAE1, Ubc9 & gastric & PIAS1, PIAS4 \\
\hline hepatocellular & $\begin{array}{l}\text { PC2, PIAS2, PIAS3, PIAS4, } \\
\text { SAE1, SAE2, SENP1, SENP3, } \\
\text { SENP5, SENP6, SUMO2, Ubc9 }\end{array}$ & glioma & PIAS3 \\
\hline leukemia & SAE1, SUMO3 & leukemia & PIAS2, SENP5, SENP7 \\
\hline lung & $\begin{array}{l}\text { PC2, SAE1, SAE2, SENP1, } \\
\text { SUMO2/3, SUMO4, Ubc9 }\end{array}$ & lung & PIAS3 \\
\hline melanoma (cutaneous) & SAE1 & melanoma (cutaneous) & PIAS1, SENP5, SENP7 \\
\hline melanoma (uveal) & SAE1, SAE2, SUMO3 & melanoma (uveal) & SENP2, Ubc9 \\
\hline mesothelioma & $\begin{array}{l}\text { PIAS3, PIAS4, SAE1, SAE2, } \\
\text { SENP1 }\end{array}$ & mesothelioma & PC2, PIAS3, SENP2 \\
\hline multiple myeloma & Ubc9 & ovarian & PIAS2 \\
\hline osteosarcoma & PC2, SENP3 & pancreatic & SENP3 \\
\hline ovarian & SENP3, SENP5 & $\begin{array}{c}\text { pheochromocytoma and } \\
\text { paraganglioma }\end{array}$ & Ubc9 \\
\hline pancreatic & $\begin{array}{l}\text { SENP2, (SUMO1 and } \\
\text { SUMO2/3 together), Ubc9 }\end{array}$ & renal & PIAS1, PIAS2 \\
\hline prostate & $\begin{array}{l}\text { PIAS1, SAE1, SENP1, SENP5, } \\
\text { SUMO1, SUMO2 }\end{array}$ & testicular germ cell & PIAS2 \\
\hline renal & $\begin{array}{l}\text { PC2, PIAS3, RSUME, SAE1, } \\
\text { SENP1, SENP3, SENP5, } \\
\text { SUMO1, SUMO2, Ubc9 }\end{array}$ & thymoma & $\begin{array}{c}\text { PIAS4, SAE1, SAE2, SENP1, } \\
\text { Ubc9 }\end{array}$ \\
\hline sarcoma & $\begin{array}{l}\text { PC2, PIAS2, PIAS3, SENP6, } \\
\text { SENP7 }\end{array}$ & & \\
\hline thyroid & PIAS2, SAE1 & & \\
\hline uterine corpus endometrial & $\begin{array}{c}\text { PC2, SAE2, SENP2, SENP5, } \\
\text { SUMO4 }\end{array}$ & & \\
\hline
\end{tabular}

\section{Genetic Changes Targeting SUMO Machinery in Cancer}

\subsection{Germline Variants}

In breast cancer patients, genetic variation of UBE2I can influence the characteristics of tumors [86,87]. Single nucleotide polymorphisms (SNPs) rs7187167, rs11248866, rs8052688, and rs8063 are associated with low-grade (grade 1) tumors, with the strongest tumor grade association displayed by rs7187167 found to be an independent predictor of tumor grade. Moreover, SNP variant rs17354559 of PIAS3 may be of functional relevance in breast cancer, 
although the variant was not evaluated experimentally [87]. Furthermore, the genetic variability of SENP1 and SENP2 may play a role in the occurrence of breast cancer [88]. The rs12297820 variant of SENP1 is associated with metastatic status in breast cancer. Women carrying allele $C$ and genotype $C / C$ in the rs 12297820 polymorphic site have an increased risk of metastases, while allele $\mathrm{T}$ is associated with reduced risk of metastases. Genetic variability of SENP2 may influence the risk and subtype of breast cancer, as allele $\mathrm{C}$ and genotype C/C in rs6762208 site correlates with reduced risk, and the A/A genotype is associated with the lack of an estrogen receptor.

Studies performed in a Chinese population indicate that genetic variation of PC2 may influence the occurrence of gastric cancer [89]. Polymorphism rs77447679 is significantly associated with the risk of gastric cancer, as patients carrying the $\mathrm{C} / \mathrm{A}$ genotype have approximately a 1.7 times higher risk of gastric cancer when compared to the baseline CC genotype, but its mode of action as a potential promoter of tumorigenesis in the context of gastric cancer is still unclear.

Microphthalmia-associated transcription factor (MITF) is a target for a germline missense substitution Mi-E318K at the SUMO consensus motif of MITF (IKQE -> IKQK) required for covalent SUMO binding, leading to the impairment of MITF SUMOylation [90,91]. The prevalence of Mi-E318K mutation is approximately five times higher in patients affected by melanoma, renal cell carcinoma (RCC), or both cancers compared with healthy controls. Overall, the data indicates that mutation of MITF generates a genetic predisposition for the development of melanoma and RCC. MITF plays a critical role in melanocyte development and melanoma carcinogenesis by controlling the expression of several melanoma-associated genes that regulate proliferation and invasion, including MET5 and CDKN2A/p16INK4A5 [92]. MITF also enhances the transcriptional activity of HIF1 $\alpha$, which is a critical target for kidney cancer susceptibility genes [93,94]. The SUMOylation of MITF represses its transcriptional activity, and accordingly the SUMO-deficient Mi-E318K displays significantly increased overall transcriptional activity when compared to its wild-type counterpart [91]. Interestingly, Mi-E318K and wild-type MITF show similar transcriptional activity on promoters of MET and CDKN2A, while the activity of HIF1 $\alpha$ is promoted more efficiently by Mi-E318K. A specific Mi-E318K signature comprising 32 genes mostly associated with cell growth, proliferation, and inflammation has been identified in RCC cells, implicating that Mi-E318K can alter the transcription of its target genes. Mi-E318K also enhances the invasion, migration, and colony-forming potential of melanoma and RCC cells but does not significantly increase their proliferation rate.

\subsection{Somatic Mutations}

Mutations targeting SUMO machinery have been identified that may contribute to development of cancer. Amplification of distal regions of chromosome $3 \mathrm{q}$ is a common event in lung cancer [95]. A network of four genes, SENP2, DCUN1D1, DVL3, and UBXN7 was identified as a candidate driver of the 3q26-29 amplicon that occurs in 70-85\% of squamous cell carcinomas (SCCs) of the lung [96,97]. In addition to lung cancer, amplifications of $3 q 26$ are also frequent in other epithelial cancers, including head and neck cancer, cervical cancer, and ovarian cancer, which may indicate for SENP2 amplification [97]. As another example, the SENP5-encompassing 3q27.2-q29 region is amplified in $11 \%$ of penile squamous cell carcinoma patients, which may indicate enhanced SENP5 activity [98]. Furthermore, the amplification of PIAS1 and/or focal adhesion kinase (FAK) occurs in $8 \%$ of non-small-cell lung cancer (NSCLC) cell lines and in a small subset of patient-derived primary NSCLCs and potentially drives lung carcinogenesis [99]. Only a few cases of somatic mutations targeting SUMO pathway components resulting in the expression of altered protein have been characterized. The $\mathrm{t}(12 ; 15)(\mathrm{q} 13 ; \mathrm{q} 25)$ chromosomal translocation was found to fuse SENP1 and the mesoderm development candidate 2 (MESDC2) in a patient with infantile sacrococcygeal teratoma [100]. The reciprocal fusion genes encode aberrant proteins that display deSUMOylation capacities similar compared with wild-type SENP1. Another example is the fusion between SENP6 (also known as SUSP1) and T-cell 
lymphoma breakpoint associated target 1 (TCBA1) that creates a SENP6-TCBA1 chimeric gene found in a T-cell lymphoblastic lymphoma cell line [101].

Somatic lysine mutations targeting the SUMO acceptor sites of substrate proteins may also lead to the dysregulation of SUMOylation and alter protein function in cancer. Interestingly, lysine mutations have been identified in cancer patients with potential functional relevance, but the extent of lysine mutations leading to aberrant SUMOylation is unknown [102,103].

\section{SUMOylation Regulates Key Cancer Genes and Hallmark Properties of Cancer Cells 5.1. Substrates of SUMO Relevant for Cancer}

Oncogenic signaling of growth promoting MYC in cancer cells is dependent on a functional SUMO machinery, indicating that dynamic SUMOylation and deSUMOylation are essential for the regulation of MYC [104]. However, the regulation is context-dependent, and SUMOylation is reported to both upregulate and suppress MYC activity, depending on the specific cell type [105-107]. SUMOylation has been suggested to be essential for KRAS/RAF-driven tumorigenesis [108] and is involved in the regulation of major growthpromoting intracellular signaling pathways and their downstream targets. SUMOylation enhances growth-promoting activities of oncogenic AKT, and a mutant form of AKT expressed in several cancers displays elevated levels of SUMOylation [109]. PIAS4-mediated SUMOylation of AMP-activated protein kinase (AMPK) in turn attenuates the inhibitory effect of AMPK towards growth-promoting mTORC1 signaling [110]. SUMOylation of hypoxia inducible factors 1 (HIF1) and 2 (HIF2) is essential for the regulation of several key processes during hypoxia, including angiogenesis, glucose metabolism and erythropoiesis $[44,82,85,111,112]$. SUMO machinery also mediates NF- $\mathrm{kB}$ signaling upon genotoxic stress through the regulation of the NF- $\mathrm{kB}$ essential modifier (NEMO) [113]. Furthermore, SUMOylation regulates activation of Wnt $/ \beta$-catenin signaling via SUMO modification of transducin $\beta$-like protein TBL1-TBLR1 complex [114].

SUMOylation modulates several tumor suppressors, such as Rb, as well as p53 and its negative regulator MDM2, regulating cell cycle progression and stress responses [115-120]. SUMOylation positively regulates the activity of tumor suppressor PTEN, which is a negative regulator of the oncogenic phosphatidylinositol-3 kinase (PI3K)-AKT pathway and is involved in DNA damage response (DDR) [121]. SUMO machinery influences membrane association and subcellular localization of PTEN, controlling its tumor-suppressive functions in both cytoplasm and nucleus, suppressing tumor growth and, in contrast to other reports, suggesting that SUMOylation is a positive regulator of the PI3K-AKT-mTOR pathway [122-124].

\subsection{SUMOylation in Cellular Processes Relevant for Cancer}

The SUMO pathway regulates various essential cellular processes involved in tumorigenesis, including cell cycle progression, stress responses such as DDR, and response to hypoxia, angiogenesis, invasion, stem-like cell properties, and immune responses [44,125-130]. For example, PIAS1 and PIAS4 are promoters of double-strand break repair, and SENPs are critical for mediating chromosome structure and homologous recombination as well as nonhomologous end joining [125,131-133]. Moreover, SUMOylation influences DNA repli-

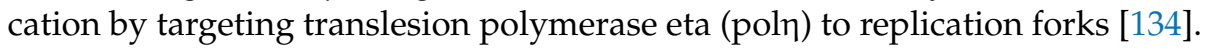

SUMO may be involved in the epigenetic regulation of gene expression in cancer. SUMOylation of histones is involved in regulation of chromatin dynamics [135]. SUMOylation may also influence the activity of methyltransferases, such as DNMT1, MLL1/MML2 complex and G9a [136-138]. PIAS1 has been shown to control epigenetic silencing of specific gene sets in certain contexts $[139,140]$. During T-cell differentiation PIAS1 maintains a repressive chromatin state of the FOXP3 promoter by recruitment of DNA methyltransferases and heterochromatin protein 1 , which restricts the differentiation of natural regulatory T-cells (Tregs) [139]. 
The SUMO pathway regulates angiogenesis in response to hypoxia through modulation of vascular endothelial growth factor (VEGF) expression levels [44,141,142]. Furthermore, SUMOylation is involved in cellular migration and epithelial mesenchymal transition (EMT) via multiple mechanisms [143-148]. The SUMO pathway is also implicated in regulation of stem-like cell properties of cancer cells e.g., via PIAS3 and STAT3 [129,149].

SUMO machinery is a critical regulator of innate immune responses via the modulation of type I interferon (IFN) and NF- KB signaling [130,150]. The SUMO pathway regulates the production and activity of IFNs by inhibiting or stimulating the transcription of IFN regulatory transcription factors (IRFs), such as IRF3 and IRF7 [151-154]. The SUMOylation of IRFs represses the transactivating capacity of IRFs, resulting in diminished transcription of type I IFN genes and attenuation of immune response activation [152,155]. SUMO also impacts IFN production via the modulation of GMP-AMP synthase (cGAS) and the stimulator of interferon genes (STING) [156,157]. SUMO also influences the activity of NF- $\kappa B$ signaling regulators, NEMO and $\mathrm{I} \kappa \mathrm{B} \alpha$, affecting immune response activation [158-162]. SENP3-mediated deSUMOylation regulates antitumor immune response functions of Tregs, macrophages, and dendritic cells [163-165]. The loss of SENP3 deSUMOylase activity in Tregs results in dysregulation T-cell homeostasis and SENP3 deficiency in macrophages facilitates macrophage polarization towards the pro-tumor M2 subtype. Overall, SUMOylation is considered to have a net inhibitory effect on immune response activation $[150,166,167]$. Depletion of Ubc9 or SAE1/2 induces a strong inflammatory response and enhances protection of viral infections in hematological xenograft mouse models.

\section{SUMOylation in Hematologic Malignancies and Solid Tumors}

The SUMO pathway contributes to the tumorigenesis of various cancer types in a context-dependent manner. Here, we discuss the best-characterized examples of the role of the SUMO pathway in the tumorigenesis of hematological malignancies and solid tumors.

\subsection{Acute Promyelocytic Leukemia}

Acute promyelocytic leukemia (APL) was one of the first clinical links between SUMO modification and cellular transformation (Figure 2A). APL is a subtype of acute myeloid leukemia (AML) characterized by the reciprocal chromosome translocation $t(15 ; 17)$ that creates the oncogenic fusion protein promyelocytic leukemia (PML)-retinoic acid receptor $\alpha(\operatorname{RAR} \alpha)$ [168-171]. The expression of PML-RAR $\alpha$ disrupts the integrity of PML nuclear bodies, which are known hotspots for SUMOylation [172-174]. RAR $\alpha$ is a hormoneregulated nuclear receptor that regulates transcription of differentiation-associated genes by recruiting corepressors, such as SMRT and N-CoR, to repress cellular differentiation [171]. RAR $\alpha$-induced gene repression is counteracted upon the binding of its natural ligands, such as all-trans-retinoic acid (ATRA) that alleviate RAR $\alpha$-maintained differentiation repression $[171,175]$. The oncogenic fusion protein PML-RAR $\alpha$ binds corepressors with a higher affinity than its wild-type counterpart and physiological levels of ATRA in APL patients are insufficient to release PML-RAR $\alpha$-maintained repression of differentiation genes, resulting in a myeloid differentiation blockade [176]. The APL differentiation block was initially attributed only to the formation of PML-RAR $\alpha$ homodimers, and the subsequent enhancement of corepressor binding and repression of target genes [177]. However, later studies revealed that the SUMOylation of PML-RAR $\alpha$ plays a major role in the pathogenesis of APL. The SUMOylation of PML at the SUMO site K160 is essential for APL initiation and maintenance, and the inactivation of K160 impairs the differentiation blockade and immortalization of APL cells [178] (Figure 2A). Mouse primary hematopoietic progenitor cells transduced with SUMO-deficient (K160R) PML-RAR $\alpha$ grow only for a limited period, and its expression in mice induces myeloid hyperplasia that does not progress to APL, indicating that APL cell immortalization and differentiation block is SUMO-dependent. 


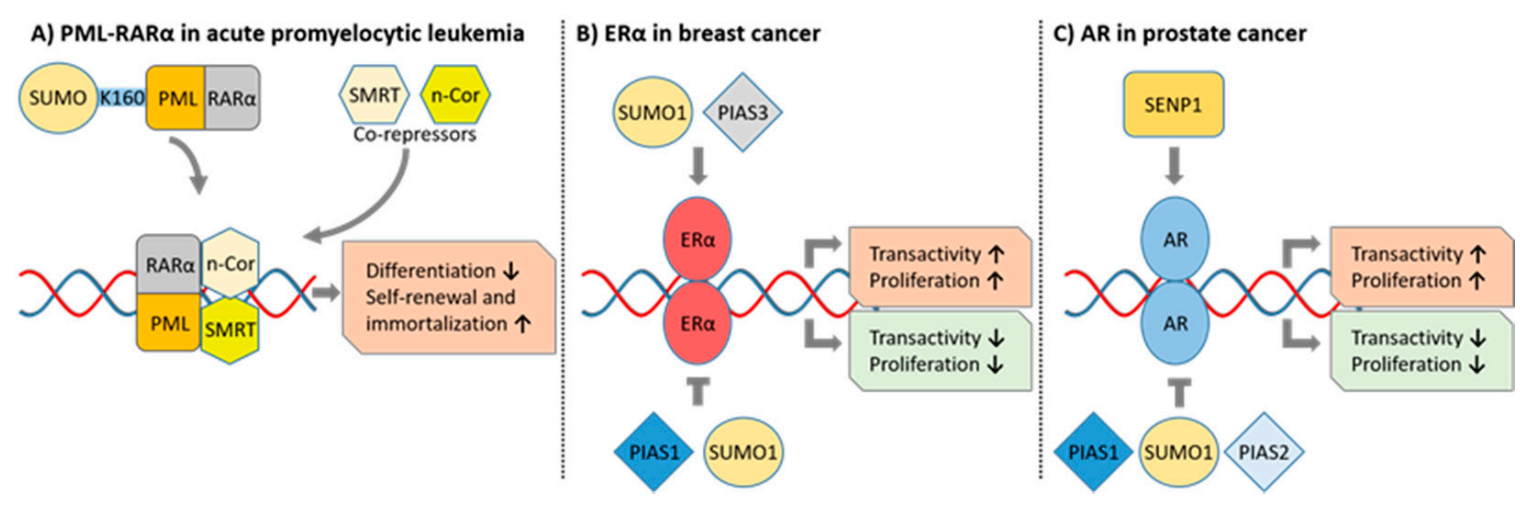

Figure 2. Examples of SUMO-modification regulation of key oncogenic substrates. (A) SUMOylation of PML-RAR $\alpha$ in K160 and recruitment of co-repressors is required for APL cell differentiation blockade, self-renewal and immortalization. (B) PIAS3 promotes transactivation of estrogen receptor $\alpha(E R \alpha)$ and proliferation of breast cancer cells via SUMO-dependent and independent mechanisms, whereas PIAS1 has a predominantly repressive effect on ER $\alpha$. (C) SENP1-mediated deSUMOylation of androgen receptor (AR) promotes AR-dependent transactivation and proliferation of prostate cancer cells that is counteracted by PIAS1- and PIAS2-induced SUMO1-modification of AR.

Differentiation therapy with ATRA in combination with arsenic trioxide (ATO) has emerged as an effective therapeutic strategy for treatment of APL [171]. ATRA and ATO synergize to induce differentiation and death of APL cells, in which ATRA alleviates the repressive chromatin environment and induces degradation of the PML-RAR $\alpha$ [179-181]. ATO enhances the binding of Ubc9 to both PML-RAR $\alpha$ and wild-type PML, triggering their SUMOylation and recruitment of ubiquitin E3 ligase ring finger protein 4 (RNF4) [182]. Mechanistically, ATO triggers SENP1-dependent exchange of SUMO1 to SUMO2 at Lys65 of PML, enhancing the formation of PML nuclear bodies and the conjugation of SUMO2 to Lys160, which results in RNF4-mediated polyubiquination and proteasomal degradation of PML-RAR $\alpha$ in nuclear bodies $[182,183]$. Overall, the data indicate that SUMOylation plays major roles in both APL development and its remedy.

\subsection{Acute Myeloid Leukemias Other Than APL}

While ATRA and ATO-based differentiation therapies are an effective treatment strategy for APL, they have failed to show significant efficacy in clinical trials of non-APL AML patients [184]. This has been attributed to differences in epigenetic and transcriptional profiles of AML subtypes. SUMOylation has been shown to repress the expression of various ATRA-responsive genes, indicating that the SUMO pathway restricts ATRA's ability to induce expression of genes associated with myeloid differentiation in non-APL AMLs [185]. Combining ATRA treatment with pharmacological inhibitors of SUMOylation, 2-D08 (inhibitor of Ubc9), or anacardic acid (inhibitor of SAE1/2), results in enhanced expression of various ATRA-responsive genes associated with myeloid differentiation, including RARA, CEBPA, and TNSFS10 [185]. A similar increase in expression of ATRAresponsive pro-differentiation genes is observed when SENP2 or SENP5 is overexpressed in AML cells [185]. ATRA synergizes with SUMOylation inhibitors to induce morphological changes of myeloid differentiation, including nuclear lobulation and appearance of cytosolic granules in several non-APL AML cell lines and primary AML cells. A combination of 2-D08 and ATRA inhibits the proliferation of AML cell lines, reduces proliferation of primary AML cells, and restricts tumor growth in immunodeficient mice subcutaneously xenografted with U937 cells. Moreover, 2-D08 induces mitochondrial-mediated apoptosis through an accumulation of ROS that is likely triggered by deSUMOylation of NOX2 [186]. Taken together, the inhibition of SUMOylation in combination with ATRA or other differentiation agents may be an attractive novel therapeutic strategy for treatment of non-APL AMLs.

Additionally, the SUMO pathway is critically involved in the regulation of DDR of AML cells via nucleophosmin (NPM) and human coilin-interacting nuclear ATPase protein 
(hCINAP) [187]. NPM is the most frequently mutated gene in non-APL AMLs [188,189]. Generation of double-strand breaks triggers the SUMOylation of NPM, which is required for its interaction with BRCA1 and accumulation of BRCA1 foci to damage sites in the early stage of DDR [187]. During the later stages of DDR, hCINAP is recruited to damage sites where it binds with SENP3, which enhances SENP3-mediated deSUMOylation of NPM and decreases the recruitment of repair proteins to prevent excessive repair $[187,190]$. The lower expression of hCINAP is associated with better prognosis in AML patients [187]. Depletion of hCINAP in patient-derived xenograft AML mice results in higher sensitivity to chemotherapy, elevated levels of DNA damage and cell death, and mitigation of AML progression. Thus, hCINAP expression levels affect DDR via the regulation of NPM SUMOylation, making hCINAP a potential therapeutic target in AML patients.

\subsection{Lymphomas}

The SUMO pathway influences development of both B- and T-cell lymphomas [106,191,192]. The aberrant activation of the SUMOylation pathway is a hallmark of MYC-driven B-cell lymphomas [106,191]. MYC expression induces the transactivation of several SUMO machinery components, including Ubc9 and PIAS1 to promote global hyper-SUMOylation in P493-6 B lymphoma cells and several Burkitt's lymphoma cell lines [191]. Furthermore, PIAS1-induced SUMOylation stabilizes MYC, and PIAS1 is implicated in facilitating transactivation-associated phosphorylation of MYC in B-cell lymphomas [106]. The silencing of SAE1, SAE2 or PIAS1 and pharmacological inhibition of SUMOylation with anacardic acid or 2-D08 reduces proliferation and induces apoptosis in various MYC-driven B lymphoma cell lines, and the silencing of SAE2 or PIAS1 significantly impairs B-cell lymphomagenesis in mouse xenograft models [106,191]. Moreover, SUMOylation contributes to pathogenesis of T-cell lymphomas expressing the oncogenic NPM-anaplastic lymphoma kinase (NPM-ALK) fusion protein via SUMO-dependent post-translational stabilization of NPM-ALK [192]. SUMO1-3 levels are upregulated in NPM-ALK+ T-cell lymphoma cell lines and ALK+ T-cell lymphoma patient tumors, whereas SENP1 levels are significantly downregulated. The introduction of SENP1 expression induces deSUMOylation of NPM-ALK, and the subsequent ubiquitination and proteasomal degradation of NPM-ALK, decreasing the viability, proliferation and anchorage-independent colony formation in NPM-ALK + T-cell lymphoma cell lines. Thus, the inhibition of SUMOylation should be explored as a therapeutic option for treatment of MYC-dependent B-cell lymphomas and NPM-ALK+ T-cell lymphomas.

\subsection{Multiple Myeloma}

Multiple myeloma (MM) is a hematological malignancy characterized by the clonal expansion of plasma cells that produce monoclonal immunoglobulin (Ig) and Ig fragments, termed M-protein or paraprotein, which are detectable in the serum or urine [193]. The SUMO pathway is often dysregulated in MM patients, and high SUMOylation is associated with adverse patient outcome [194]. The overexpression of Ubc9, SENP1, PIAS1, and SUMO-inducer p14ARF are frequently observed in MM patient samples and MM cell lines [194,195]. While p14ARF is not traditionally considered as a part of the classical SUMO machinery, it interacts with Ubc9 to trigger the SUMOylation of many of its binding partners, such as NPM and MDM2 [118,196,197]. The induction of Ubc9 expression in MM is associated with increased proliferation and apoptotic resistance, and enhanced adhesion of MM cells to bone marrow stroma cells (BMSCs) [194]. The adhesion of MM cells to BMSCs induces interleukin-6 (IL-6) secretion and activation of the NF- $\mathrm{kB}$ pathway, which further stimulates proliferation of MM cells [194,198-200]. MM cells transfected with a functionally inactive dominant-negative form of Ubc9 display a decreased proliferation rate, are more sensitive to radiation-induced apoptosis, and have a weaker proliferative response in the presence of BMSCs when compared to wild-type Ubc9-expressing MM cells [194]. Aberrant IL-6 signaling upregulates expression of SENP1 at least partly through the induction of the JAK-STAT-signaling pathway, and the treatment of MM cells with 
JAK-STAT inhibitor AG490 diminishes IL-6-mediated upregulation of SENP1 [195]. The knockdown of SENP1 with shRNA results in significantly increased SUMO2 levels and blocks the IL-6-induced activation of NF- $\mathrm{KB}$ family member p65, implicating that SENP1 positively regulates NF- $\mathrm{KB}$ signaling via SUMO modification of NF- $\mathrm{kB}$ family members. Furthermore, the knockdown of SENP1 reduces viability, proliferation, and colony-forming potential, as well as induces apoptosis in MM cells.

The downregulation of SENP2 in MM patients is associated with drug resistance against bortezomib, which is a widely used proteasome inhibitor for treatment of MM [56]. In MM patients, low SENP2 expression levels result in aberrant activation of NF- $k B$ signaling [56]. The NF- $\mathrm{kB}$ pathway is normally regulated by a negative feedback mechanism, where NF- $\mathrm{kB}$ activates expression of SENP2, which in turn inhibits NF- $\mathrm{kB}$ signaling. However, the silencing of SENP2 in MM through yet-unknown mechanisms results in enhanced SUMOylation of $\mathrm{I} \kappa \mathrm{B} \alpha$, activation of NF- $\kappa \mathrm{B}$ signaling and development of bortezomib resistance in MM patients. Identifying SUMO ligases that regulate IKB $\alpha$ is important, as they may serve as novel therapeutic targets in bortezomib-resistant MM. Overall, the dysregulation of SUMO pathway is widespread in MM, which encourages further studies to characterize which SUMO components or their regulatory targets have most therapeutic or prognostic value. Pharmacological inhibition of SUMOylation and SENP1 may have therapeutic potential for treatment of MM.

\subsection{Breast Cancer}

The SUMO pathway has a multifunctional role in the regulation of growth and the invasion and metastasis of breast cancer cells [201-203]. In hormone receptor (HR)positive breast cancer, the SUMO pathway is an essential regulator of estrogen receptor $\alpha(E R \alpha)$ (Figure 2B) [204]. PIAS1 and PIAS3 modulate transactivation of ER $\alpha$ through its direct SUMOylation that occurs strictly in the presence of the hormone, and via the SUMOylation of ER $\alpha$ cofactors (Figure 2B). However, PIAS1, PIAS3, and Ubc9 also regulate $\mathrm{ER} \alpha$ transactivation in a SUMO-independent manner. The induction of SUMO-deficient $\mathrm{ER} \alpha$ to COS-7 cells reduces the transactivation of $\mathrm{ER} \alpha$, indicating that SUMOylation of $E R \alpha$ may promote its transactivation. However, excessive SUMOylation of ER $\alpha$ is linked to repression of ER $\alpha$ transactivation. Tumor suppressor MEL-18 regulates ER $\alpha$ activity by suppressing the SUMOylation of ER $\alpha$ transactivators p53 and Sp1 to promote ER $\alpha$ and progesterone receptor (PR) activity, and MEL-18 may be a prognostic marker and predictor of response to antihormonal therapy in breast cancer [205]. SUMOylation is also important for mechanisms of action of antiestrogens in the treatment of HR-positive breast cancer [206]. Interestingly, the upregulation of PIAS1 is associated with epigenetic silencing of breast cancer-associated genes, including ESR1 (ER $\alpha$ ) [140]. Thus, PIAS1 can both upregulate and downregulate ER $\alpha$ activity in breast cancer. PIAS1 also promotes the SUMOylation of transcriptional regulator SnoN that suppresses TGF $\beta$-induced EMT in ER-positive MCF7 cell-derived organoids [148]. In contrast, PIAS3 stimulates proliferation of ER-positive breast cancer cells, and PIAS3 acts as a co-activator to regulate NR2E3mediated activation of ESR1 (ER $\alpha)$ expression $[207,208]$. PIAS3 is involved in the regulation of receptor tyrosine kinase ErbB4 $[209,210]$. ErbB4 can be proteolytically cleaved to release an intracellular domain (ICD) that acts as a transcriptional co-regulator implicated in the regulation of differentiation and proliferation of mammary epithelial cells [211-213]. PIAS3 interacts with ErbB4 ICD to induce its SUMOylation, which promotes its nuclear accumulation and may facilitate autokinase activity of ErbB4 [209,210]. Interestingly, nuclear ErbB4 immunoreactivity is associated with a poor survival of ER-positive patients when compared to cell surface expression [213]. Thus, inhibition of PIAS3 may be an attractive therapeutic target in HR-positive breast cancer, but although the targeting of PIAS1 in breast cancers overexpressing PIAS1 could potentially relieve PIAS1-mediated epigenetic repression, the role of PIAS1 as a repressor of invasion must be considered.

In triple-negative breast cancer (TNBC), PIAS1 promotes the SUMOylation of SnoN that suppresses TGF $\beta$-induced EMT in TNBC MDA-MB-231 cell-derived organoids simi- 
larly to HR-positive breast cancer models [148,214]. Moreover, the induced expression of PIAS1 suppresses TGF $\beta$-induced activation of invasion promoter matrix metalloproteinase 2 (MMP2) in MDA-MB-231 cells, and PIAS1 knockdown in TGF $\beta$-treated MDA-MB-231 cell organoids results in morphological changes associated with invasion [214]. However, PIAS1 is essential for viability of MYC-dependent breast cancer cells, as the silencing of PIAS1 reduces the proliferation of MYC-dependent MDA-MB-231 cells, but not MYCindependent MCF7 cells [106]. MYC signaling is elevated in TNBC, and the interaction of PIAS1 with MYC drives its SUMOylation-dependent stabilization and upregulation of MYC target gene transcription $[104,106]$. PIAS3 inhibits proliferation and EMT in MDAMB-231 TNBC cells in contrast to pro-proliferation effects observed in ER-positive breast cancer $[203,208]$. PIAS3 enhances the SUMOylation of E3 ubiquitin ligase Smurf2, facilitating the degradation of TGF $\beta$ receptors, and subsequently suppressing the invasive growth of MDA-MB-231 cells [203]. The knockdown of PIAS3 induces invasion-associated morphological changes in MDA-MB-231 organoids, indicating that Smurf2's ability to limit EMT is SUMO-dependent. Overall, the contradictory observations of PIAS3 effects in TNBC and HR-positive breast cancer may suggest that different effects of PIAS3 on breast cancer cells may involve ER, whereas therapeutic targeting of SUMOylation and PIAS1 may be an effective strategy for the treatment of MYC-dependent breast cancers. In addition, the overexpression of PML is associated with high invasive tumor grade in TNBC patients, suggesting PML as a putative therapeutic target in TNBC [215].

SENP1 and SENP5 are implicated in regulation of invasiveness of TNBC [202,216]. SENP1 expression is upregulated in TNBC tissues compared to normal breast tissues and non-TNBC tissues [216]. Silencing of SENP1 reduces proliferation, invasion and colony formation of TNBC cell lines and reduces tumor size and lung metastases in a TNBC mouse xenograft model. High expression of the SENP5 gene is associated with poor prognosis in breast cancer patients [202]. The silencing of SENP5 has a profound inhibitory effect on the invasiveness of TNBC MDA-MB-231 and MDA-MB-436 cells, which is not observed in less invasive ER-positive MCF7 and T47D cells. The knockdown of SENP5 in TNBC cells significantly reduces the level of MMP9 and decreases levels of total, phosphorylated, and SUMOylated TGF $\beta R$ I, which is a stimulator of invasion at later stages of breast cancer. However, the exact mechanism of how SENP5 regulates TGF $\beta$ RI, and invasion remain to be elucidated. Pharmacological inhibition of SENP1 and SENP5 may have therapeutic potential for treatment of TNBCs overexpressing SENP1 or SENP5.

Lastly, expression of long splice variant of SENP7 (SENP7L) is associated with the promotion of EMT in both ER-positive breast cancer and TNBC and its expression is upregulated in breast cancer tissues compared to normal breast epithelia tissues [201]. SENP7L-induced deSUMOylation of epigenetic remodeler heterochromatin protein $1 \alpha$ $(\mathrm{HP} 1 \alpha)$ promotes EMT by maintaining HP1 $\alpha$ at a hypo-SUMOylated state, relieving its repression of mesenchymal promoting genes.

\subsection{Prostate Cancer}

PIAS family members promote prostate cancer $(\mathrm{PCa})$ tumorigenesis through the inhibition of CDK p21 levels and modulation of androgen receptor (AR) signaling, which is the most important known growth promoting pathway in PCa (Figure 2C) [217-219]. PIAS1, PIAS2, PIAS3, and PIAS4 are co-regulators that selectively enhance or repress transcription of AR target genes via both SUMO-dependent and -independent mechanisms [217,218,220-223]. For instance, PIAS1- and PIAS2-induced SUMOylation of AR represses its transcriptional activity. However, PIAS1 can also enhance AR-mediated upregulation of growth-promoting genes independent of its SUMO-ligase activity to drive proliferation PCa cells, and high PIAS1 expression is associated with poor survival. In contrast, PIAS3 represses the transcriptional activity of STAT5 that is a regulator of growth and viability of PCa cells, and is constitutively active in PCa and associated with high histological grade [224,225]. PIAS3mediated SUMOylation of STAT5 is reported to inhibit its activation-associated phosphorylation in COS-1 cells, which may indicate that PIAS3 mode of action on STAT5 repression 
is partially SUMO-dependent [226]. Interestingly, a subset of PCa cells express an Nterminally cleaved form of STAT5 that cannot be targeted by PIAS3 [227]. However, the extend of SUMOylation-dependent effects in PIAS-mediated outputs on PCa is not clear.

SUMO machinery can both repress and activate AR signaling in a target gene-selective manner [228-230]. SUMO1-modification inhibits AR transactivation capacity, whereas SUMO2 and SUMO3 are reported to stimulate AR activity in PCa cells, although likely independent of direct AR SUMOylation [228,229]. Overall, the SUMOylation of AR is shown to repress transcription of various AR target genes, while SENP1-induced deSUMOylation is linked to the promotion of AR transactivation capacity [230] (Figure 2C). The expression of SENP1 is frequently observed in PCa and precancerous prostatic intraepithelial neoplasia (PIN) tissues, and the overexpression of SENP1 correlates with increased aggressiveness and recurrence of PCa [142,231]. Elevation of SENP1 mRNA is selectively mediated through the activation of AR in PCa cells [232]. SENP1 also enhances AR-dependent transcription through the deSUMOylation of histone deacetylase 1 (HDAC1), diminishing its ability to repress AR [233]. HDAC4 is another SUMO-dependent repressor of AR and may be regulated by SENPs [234].

In addition to the regulation of AR transactivation capacity, SENP1 stimulates proliferation of PCa cells via an AR-independent induction of cyclin D expression, and the silencing of SENP1 results in the downregulation of cyclin D and inhibition of cell growth [231]. During hypoxia, SENP1 deSUMOylates and stabilizes HIF1 $\alpha$, promoting angiogenesis and invasion via the upregulated expression of MMP2, MMP9, and VEGF [44,141,142]. SENP1 expression in PCa patient samples positively correlates with the expression of MMP2 and MMP9 that are frequently overexpressed in prostate cancer [142]. SENP1 promotes invasion also through the deSUMOylation of reptin, diminishing its repressive effect on invasion and metastasis [235]. Furthermore, the SUMOylation status of reptin modulates the invasive activity of cancer cells with metastatic potential.

The genetic silencing of SENP1 or pharmacological inhibition with momordin Ic or triplotide reduces colony formation, migration, and invasion in PCa cell lines, as well as suppresses tumor growth in mouse PCa xenograft models [142,236,237]. Interestingly, SENP1 positively regulates the stability of tumor suppressor PTEN by blocking its SUMOdependent ubiquitylation and degradation [238]. PTEN is considered to serve as a barrier for SENP1-induced PCa tumorigenesis, and the inhibition of SENP1 may be a therapeutic option for treatment of aggressive PTEN-deficient PCa. SUMOylation controls the subcellular localization of hexokinase 2 (HK2), which is a regulator of glycolysis and has oncogenic potential when it binds to mitochondria [239]. SENP1-induced deSUMOylation stimulates HK2 binding with mitochondria to promote metabolic reprogramming, supporting proliferation of PCa cells and protecting them from chemotherapy-mediated apoptosis. The knockdown of Ubc9 increases the binding of HK2 to mitochondria, whereas the knockdown of SENP1 reduces binding to mitochondria, indicating that SUMOylation is necessary for protection against PCa tumorigenesis. High expression of both SENP1 and HK2 is associated with poor prognosis and poor response to docetaxel-based chemotherapy in PCa patients. Moreover, SENP1 regulates deSUMOylation of spliceosome factor USP39 that is implicated in PCa tumorigenesis [240]. The introduction of SUMO-deficient USP39 enhances its ability to promote proliferation of both androgen-dependent and -independent PCa cells, suggesting that deSUMOylation can enhance its oncogenic activity. Taken together, pharmacologic inhibition of SENP1 may be an attractive option for the treatment of PCa due to SENP1's various oncogenic functions.

Lastly, androgen-dependent GTPase-activating protein-binding protein 2 (G3BP2) interaction with RanBP2 mediates SUMOylation of p53 that induces its export to cytoplasm, repressing tumor-suppressive functions of p53 [241]. Elevated cytoplasmic p53 localization correlates with increased G3BP2 expression and is associated with disease progression to the hormone-refractory state and poor prognosis. The silencing of RanBP2 inhibits dihydrotestosterone (DHT) mediated nuclear export of p53, and the depletion of G3BP2 increases nuclear levels of p53 and reduces tumor growth in PCa mouse xenograft models. 
Thus, therapeutic targeting of RanBP2 or G3BP2 may offer therapeutic advantages in PCa expressing high levels of cytoplasmic p53.

\subsection{Kidney Cancer}

Renal cell carcinomas (RCCs) are characterized by diminished activation of E3 ubiquitin ligase VHL [94]. Prolyl 4-hydroxylases hydroxylate HIFs and facilitate the binding of E3 ubiquitin ligase VHL to HIFs that promotes their ubiquitination and proteasomal degradation in normoxia, but in hypoxic conditions HIFs are stabilized [242,243]. HIFs regulate the expression of several genes involved in energy metabolism, angiogenesis, and cell proliferation. In RCC, the stabilization of HIFs due to lack of VHL activity supports tumor growth, and the HIF-VEGF axis is a target for therapeutics used in the treatment of RCC patients [94]. SUMOylation-related deregulation of HIF1 $\alpha$ and HIF2 $\alpha$ transactivation are strongly implicated in development of RCCs [44,244,245]. Regulatory axis of VHL, SENP1, and SUMO-enhancer RSUME is essential for the modulation of HIF activity in response to hypoxia. Hypoxia induces SENP1-mediated deSUMOylation of HIFs, promoting the stabilization and transactivation of both HIF $1 \alpha$ and HIF $2 \alpha$ by protecting them from VHL-mediated proteasomal degradation [44,244]. Tissues from clear-cell RCC (ccRCC) patients expressing high levels of SENP1 display increased expression of various glycolytic enzymes, and high SENP1 expression is associated with poor prognosis in ccRCC patients [245]. In addition, protein levels of HIF1 $\alpha$ and HIF $2 \alpha$ are upregulated in ccRCC tumors when compared to normal tissues. The knockdown of SENP1 decreases proliferation of RCC4/VHL cells in hypoxic conditions and reduces mRNA levels of key glycolytic enzymes such as PGK1, PFK1, and ALDOA, and hypoxia-response genes VEGF and $M M P-9$ more potently under hypoxia compared to normoxia. Mechanistically, SENP1 enhances aerobic glycolysis through deSUMOylation and stabilization of HIF1 $\alpha$, which in turn upregulates transcription of glycolysis-related genes in ccRCC. Transfection of RCC4/VHL cells with SUMO-defective HIF1 $\alpha$ results in increased mRNA levels of HIF1 $\alpha$ transactivation target genes, supporting that deSUMOylation of HIF1 $\alpha$ drives the upregulation of glycolytic enzymes and other downstream genes. Thus, increased SENP1 and HIF1 $\alpha$ activity promote RCC development at least in part by inducing a metabolic shift towards aerobic glycolysis.

RSUME is reported to stabilize and enhance transactivation of HIF1 $\alpha$ via induction of HIF1 $\alpha$ SUMOylation in response to hypoxia, which partially contradicts the model in which HIF1 $\alpha$ is activated by deSUMOylation [111,112]. However, later studies advocated for an alternative mechanism for RSUME-mediated activation of HIF1 $\alpha$ and HIF2 $\alpha$, in which RSUME counteracts the negative regulator of HIF, E3 ubiquitin ligase VHL [246,247]. RSUME interacts with VHL, which promotes the SUMOylation of VHL and inhibits its assembly, thus blocking the proteasomal degradation of HIF1/2 $\alpha$ [246]. RSUME is also suggested to potentiate VHL mutant phenotype [247]. Taken together, the targeting of the SUMO pathway and SENP1/HIF1 $\alpha$ axis with pharmacological inhibitors of SENP1 may have therapeutic potential in treatment of RCC.

\subsection{Lung Cancer}

PIAS1-mediated SUMOylation induces autophosphorylation and activation of FAK, which is a regulator of cytoskeleton remodeling, mitogenic signaling, and cell survival [248]. PIAS1 also regulates the subcellular localization of FAK [99]. Co-amplification PIAS1 and FAK is reported in a subset of non-small-cell lung cancers (NSCLCs). PIAS1-mediated nuclear recruitment of FAK promotes DNA damage repair, which may provide a survival advantage to genomically unstable NSCLC tumors. Hypoxia-induced Ubc9- and PIAS4mediated SUMOylation of migration regulator Slug enhances its transcriptional repression activity by recruitment of corepressors, decreasing expression of Slug downstream targets, such as E-cadherin [249]. SUMOylation of Slug promotes migration, invasion, and metastasis in lung cancer cells. The overexpression of Ubc9 or Slug is associated with poor prognosis in NSCLC patients, whereas a combined low expression level of Slug and 
Ubc9 is linked to better survival. PIAS3 in turn suppresses the proliferation of lung cancer cells through SUMO-independent inhibition of STAT3 and PI3K/AKT signaling, as well as via the promotion of apoptosis [250-253]. PIAS3 protein levels are often downregulated, and low PIAS3 expression is associated with poor survival of squamous cell lung cancer patients [80,254]. Induced overexpression of PIAS3 in NSCLC cell lines decreases proliferation through suppression of AKT phosphorylation and reduced transactivation of STAT3 [251,252]. PIAS3 overexpression promotes STAT3- and p53-independent apoptosis through activation of intrinsic apoptotic pathway in NSCLC cell lines [253]. PIAS3 overexpression also potentiates anti-proliferative effects of erlotinib, which is an EGFR inhibitor used in NSCLC therapies [252]. Moreover, SENP2 is frequently overexpressed in lung cancer due to the prevalence of the 3q26-29 amplicon [96,97]. The network of SENP2, DCUN1D1, DVL2, and UBXN7 regulates proliferation of lung cancer cells that carry the 3q26-29 amplicon, as knockdown of any of the four proteins leads to inhibition of growth [96]. High expression of the three-gene signature of SENP2, DCUN1D1, and DVL3 may also predict benefit from adjuvant chemotherapy in SCC patients. Thus, amplified PIAS1 and SENP2 are potential therapeutic targets in lung cancer, whereas the expression level of PIAS3 may predict sensitivity towards select treatments.

\subsection{Hepatocellular Carcinoma}

SENP1 regulates hepatocellular carcinoma (HCC) carcinogenesis through deSUMOylation of ubiquitin-conjugating enzyme E2T (UBE2T) and HIF1 $\alpha[255,256]$. SENP1-mediated deSUMOylation of UBE2T promotes HCC development through activation of the PI3KAKT pathway, and both SENP1 and UBE2T are overexpressed in most HCC tissues and hepatoma cell lines. A positive feedback loop between SENP1 and HIF1 $\alpha$ is implicated to contribute to the maintenance of HCC cell stemness under hypoxia. The knockdown of SENP1 decreases proliferation, colony formation, invasion, and stemness of HCC cells, and reduces tumor growth in mouse xenograft models, indicating SENP1 as a potential therapeutic target in HCC. PC2-mediated SUMOylation and transactivation of HIF1 $\alpha$ drives angiogenesis and HCC tumorigenesis via hypoxia-induced upregulation of VEGF expression [68]. Moreover, SUMOylation of Shp2 promotes ERK-mediated promotion of HCC cell and tumor growth [257]. Taken together, the inhibition of SUMOylation and SENP1 may have therapeutic potential in HCC.

\subsection{Gliomas}

Protein levels of SUMO1, SUMO2/3 and Ubc9 are upregulated in patient samples derived from astrocytic tumors, with a moderate upregulation in low-grade astrocytoma (grade 2) and anaplastic astrocytoma (grade 3), and a massive upregulation in glioblastoma multiforme (GBM; grade 4) [258]. Furthermore, high protein expression of SAE1 is associated with poor prognosis of glioma patients [67]. Silencing of SUMO1-3 reduces proliferation and clonogenic survival, and suppresses DNA repair and synthesis in GBM cells [258]. Mechanistically, SUMO1-modification of CDK6 blocks its ubiquitinmediated proteosomal degradation to drive proliferation of GBM cells [259]. Moreover, SAE1 enhances SUMO1-modification and activation-associated phosphorylation of AKT, promoting the proliferation and migration of glioma cells [67]. Interestingly, SAE inhibitors ginkgolic and anacardic acid fail to decrease global SUMOylation in GBM cell lines, which may be due to especially high levels of SUMOylation in GBM [260]. Topotecan, an inhibitor of DNA topoisomerase I, can significantly reduce global SUMOylation in GBM cell lines [260]. Topotecan suppresses cell cycle progression via CDK6 and alters HIF1 $\alpha$ associated metabolic programming by the inhibition of pentose phosphate pathway and glycolytic metabolism in GBM.

PIAS3 is implicated in the regulation of stem-like cell properties of GBM cells [129,149]. SMAD6 induces ubiquitin-mediated degradation of PIAS3 in GBM cells to enhance STAT3mediated proliferation and stem-like cell initiation, whereas TRIM8 represses PIAS3 through a similar mechanism to maintain STAT3-mediated stemness and self-renewal 
of GBM stem-like cells. PIAS3 is downregulated in GBM tissues, likely due to ubiquitinmediated proteosomal degradation [81]. Intriguingly, SUMO1, but not SUMO2/3, appears to play a major role for maintenance of GBM stem-like cells, and PML is the major substrate for SUMO1 in these cells, facilitating stabilization of c-Myc [261]. Overall, the inhibition of SUMOylation may be an attractive strategy for treatment of GBM.

\section{Therapeutic Targeting of the SUMO Pathway}

The SUMO pathway is increasingly viewed as a potential therapeutic target in cancer [262], and several inhibitors of SUMO E1-activating, E2-conjugating and deconjugating enzymes have been identified (Table 2).

\subsection{SUMO E1 Inhibitors}

Ginkgolic acid and its structural analog, anacardic acid, were the first compounds identified to inhibit the SUMO pathway [263]. Ginkgolic acid inhibits SUMOylation by binding to SAE and blocks the formation of E1-SUMO intermediates. Other natural products similarly targeting SUMO E1 activity include antibiotic kerriamycin B, ellagitannin davidiin and tannic acid (Table 2) [264-266]. However, natural source-derived SAE inhibitors function mainly in micromolar range and can have several non-SUMO-related effects in cells, which may complicate the interpretation of their anti-cancer mechanisms. Recent advances in the development of synthetic inhibitors have enabled more specific and efficient targeting of the SUMO pathway. Synthetic inhibitors of SAE include compound 9, compound 21, various pyrazole and thiazole urea-containing compounds, ML-792, COH000, ML-93, several ginkgolic acid derivatives, and most recently, TAK-981 [267-275]. For example, compound 21 and $\mathrm{COH} 000$ act in a similar way as the natural SAE inhibitors. In contrast, ML-93, ML-792, and its derivative TAK-981 inhibit SAE activity by forming a covalent adduct with SUMO, which is catalyzed in an ATP-dependent manner by SAE1/2 itself. TAK-981 is an especially potent inhibitor of SUMOylation that can activate a strong antitumor immune response [275-278]. TAK-981 reduces proliferation of HCT116 colon cancer cells in vitro and significantly decreases tumor volumes in HCT-116 and OCI-Ly10 mouse xenograft models in vivo. TAK-981 treatment triggers the upregulation of type I IFN signaling in immune cells, as well as IFN-dependent activation of macrophages, T-cells, natural killer (NK) cells, and dendritic cells.

\subsection{SUMO E2 Inhibitors}

Pharmacological targeting of Ubc9 has generated much interest in cancer research, as it is the sole E2-conjugating enzyme known in mammals. Several inhibitors of Ubc9 have been identified, including natural product spectomycin $\mathrm{B} 1$ and its structural relatives chaetochromin A and viomellein, semisynthetic SUMO-based Ubc9 inhibitors (SUBINs), as well as synthetic inhibitors GSK145A, compound 2 and 2-D08 (Table 2) [279-283]. Antibiotic spectomycin B1 binds to Ubc9 blocking the formation of the E2-SUMO intermediates [279]. Spectomycin B1 treatment suppresses $\beta$-estradiol-dependent proliferation of MCF7 breast cancer cells. SUBINs are high-affinity SUMO2 variants that bind to Ubc9 to inhibit polySUMO chain formation [283]. GSK145A acts as a SUMO substrate mimic that is strongly targeted for SUMOylation, resulting in the depletion of available SUMO-Ubc9, whereas compound 2 directly binds to Ubc9 [280,282]. 2-D08 inhibits the transfer of SUMO proteins from Ubc9 to target substrates [281]. 2-D08 displays antiproliferative activity in several AML cell lines and bladder cancer T24 and 5637 cell lines, as well as suppresses migration of K-Ras-mutated MiaPaCa-2 pancreatic cancer cells [185,284,285].

\subsection{SENP Inhibitors}

SUMO-deconjugation machinery is frequently dysregulated in cancer, and high expression of different SENP proteases is associated with tumorigenesis of several cancers (Table 1 and Table S1), indicating SENPs as potential therapeutic targets [286]. Triplotide and momordin Ic (Mc) are natural SENP1 inhibitors that have shown anticancer activity 
towards prostate cancer (Table 2) [236,237]. Triplotide and momordin Ic decrease the proliferation of LNCaP and PC3 cell lines and inhibit tumor growth in PC3 xenograft mice models. In addition, various synthetic inhibitors of SENP1 have been developed, including compound 38, compound J5, compound 4 (GN6958), compound 13m, and compounds 6,7 , and 10 [287-291]. However, in vivo data of synthetic SENP1 inhibitors in cancer models are lacking. To date, only a few specific SENP2 inhibitors have been discovered, including compounds 69, 117, and ebselen [292,293]. URB597, a fatty acid amide hydrolase inhibitor, indirectly inhibits SENP3 by decreasing levels of ROS in rats with chronic cerebral hypoperfusion [294]. JCP666, VEA260, VEA499, compound 1, compound 3, and antibiotic streptonigrin inhibit activities of both SENP1 and SENP2 simultaneously, whereas SI2 additionally inhibits SENP3 [240,295-299]. Various benzothiophene-2-carboxamide derivatives simultaneously inhibit activities of SENP1, SENP2, and SENP5 [300]. Lastly, SPI-01 targets SENP1, SENP2, and SENP7, while VEA561 inhibits SENP2, SENP6, and SENP7 [295,301].

Table 2. Preclinical development of inhibitors targeting SUMO pathway. IC50 = half maximal inhibitory concentration of SUMOylation or deSUMOylation.

\begin{tabular}{|c|c|c|c|c|c|}
\hline Target & Inhibitor & Product Type & Activity & IC50 $(\mu \mathrm{M})$ & Study \\
\hline \multirow{14}{*}{ SAE1/2 } & Ginkgolic acid & Natural & $\begin{array}{l}\text { In vivo and } \\
\text { in vitro }\end{array}$ & 3.0 & [263] \\
\hline & Anacardic acid & Natural & $\begin{array}{l}\text { In vivo and } \\
\text { in vitro }\end{array}$ & 2.2 & [263] \\
\hline & Kerriamycin B & Natural & In vitro & 11.7 & [264] \\
\hline & $\begin{array}{l}\text { SUMO-AMSN and } \\
\text { SUMO-AVSN }\end{array}$ & Semisynthetic & In vitro & & [302] \\
\hline & Compound 9 & Synthetic & In vitro & 13.4 & [267] \\
\hline & Compound 21 & Synthetic & In vitro & 14.4 & [268] \\
\hline & $\begin{array}{l}\text { Pyrazole and } \\
\text { thiazole urea } \\
\text { containing } \\
\text { compounds }\end{array}$ & Synthetic & In vitro & $13.8-100$ & [269] \\
\hline & Davidiin & Natural & In vitro & 0.15 & [265] \\
\hline & Tannic acid & Natural & $\begin{array}{l}\text { In vivo and } \\
\text { in vitro }\end{array}$ & 12.8 & [266] \\
\hline & ML-792 & Synthetic & In vitro & $\begin{array}{l}0.003 \text { (SUMO1), } \\
0.011 \text { (SUMO2) }\end{array}$ & {$[270]$} \\
\hline & СОH000 & Synthetic & $\begin{array}{c}\text { In vivo and } \\
\text { in vitro }\end{array}$ & 0.2 & {$[271,272]$} \\
\hline & ML-93 & Synthetic & In vitro & 0.037 & [273] \\
\hline & $\begin{array}{c}\text { Ginkgolic acid } \\
\text { derivatives }\end{array}$ & Synthetic & In vitro & $5-50$ & [274] \\
\hline & TAK-981 & Synthetic & $\begin{array}{l}\text { In vivo and } \\
\text { in vitro }\end{array}$ & nM range & [275] \\
\hline \multirow{5}{*}{ Ubc9 } & GSK145A & Synthetic & In vitro & 12.5 & [280] \\
\hline & 2-D08 & Synthetic & In vitro & 6.0 & [281] \\
\hline & Spectomycin B1 & Natural & $\begin{array}{l}\text { In vivo and } \\
\text { in vitro }\end{array}$ & 4.4 & [279] \\
\hline & SUBINs & Semisynthetic & In vitro & 0.025 & [283] \\
\hline & Compound 2 & Synthetic & In vitro & 74 & [282] \\
\hline
\end{tabular}


Table 2. Cont.

\begin{tabular}{|c|c|c|c|c|c|}
\hline Target & Inhibitor & Product Type & Activity & IC50 $(\mu \mathrm{M})$ & Study \\
\hline \multirow{7}{*}{ SENP1 } & Compound 38 & Synthetic & In vitro & 9.2 & [287] \\
\hline & Triptolide & Natural & $\begin{array}{l}\text { In vivo and } \\
\text { in vitro }\end{array}$ & $0.071-0.076$ & [236] \\
\hline & Compound J5 & Synthetic & In vitro & 2.385 & [288] \\
\hline & $\begin{array}{l}\text { Compound } 4 \\
\text { (GN6958) }\end{array}$ & Synthetic & In vitro & 29.6 & [289] \\
\hline & Compound $13 \mathrm{~m}$ & Synthetic & In vitro & 3.5 & [290] \\
\hline & Momordin Ic (Mc) & Natural & $\begin{array}{l}\text { In vivo and } \\
\text { in vitro }\end{array}$ & 15.37 & [237] \\
\hline & $\begin{array}{l}\text { Compounds 6, } 7 \\
\text { and } 10\end{array}$ & Synthetic & In vitro & $3.7,0.99,7.5$ & [291] \\
\hline \multirow{2}{*}{ SENP2 } & $\begin{array}{l}\text { Compounds } 69 \\
\text { and } 117\end{array}$ & Synthetic & In vitro & $5.9,3.7$ & [292] \\
\hline & Ebselen & Synthetic & $\begin{array}{l}\text { In vivo and } \\
\text { In vitro }\end{array}$ & 2.0 & [293] \\
\hline SENP3 & URB597 & Synthetic & & & [294] \\
\hline \multirow{10}{*}{ SENP1/2/3/5/6/7 } & JCP666 & Natural & In vitro & $\begin{array}{l}13.8 \text { (SENP1), } \\
7.0 \text { (SENP2) }\end{array}$ & {$[295,296]$} \\
\hline & VEA260 & Synthetic & In vitro & $\begin{array}{l}7.1 \text { (SENP1), } \\
3.7 \text { (SENP2) }\end{array}$ & {$[295,296]$} \\
\hline & VEA499 & Synthetic & In vitro & $\begin{array}{c}3.6 \text { (SENP1), } 0.25 \\
\text { (SENP2) }\end{array}$ & [295] \\
\hline & Compound 1 & Synthetic & In vitro & $\begin{array}{l}\text { 5-10 (SENP1), } \\
\text { 5-10 (SENP2) }\end{array}$ & [297] \\
\hline & Compound 3 & Synthetic & In vitro & $\begin{array}{l}3.55 \text { (SENP1), } \\
2.98 \text { (SENP2) }\end{array}$ & [298] \\
\hline & Streptonigrin & Natural & In vitro & $\begin{array}{l}0.518 \text { (SENP1), } \\
6.919 \text { (SENP2) }\end{array}$ & [299] \\
\hline & SI2 & Synthetic & In vitro & $\begin{array}{c}1.29 \text { (SENP1), } \\
\text { unknown (SENP2), } \\
\text { unknown (SENP3) }\end{array}$ & [240] \\
\hline & $\begin{array}{l}\text { Benzothiophene-2- } \\
\text { carboxamide } \\
\text { derivatives }\end{array}$ & Synthetic & In vitro & $\begin{array}{c}0.76-35.8 \text { (SENP1) } \\
0.56-75.6 \text { (SENP2), } \\
2.4-100 \text { (SENP5) }\end{array}$ & [300] \\
\hline & SPI-01 & Synthetic & In vitro & $\begin{array}{c}5.9 \text { (SENP1), } 2.9 \\
\text { (SENP2), } 3.5 \\
\text { (SENP7) }\end{array}$ & [301] \\
\hline & VEA561 & Synthetic & In vitro & $\begin{array}{c}5.7 \text { (SENP2), } 4.2 \\
\text { (SENP6), } 4.3 \\
\text { (SENP7) }\end{array}$ & [295] \\
\hline
\end{tabular}

\subsection{Current Stage of Clinical Development of SUMO Pathway Inhibitors}

Growing evidence from numerous preclinical studies indicates that pharmacological targeting of the SUMO pathway may be an effective therapeutic strategy in certain cancers. However, clinical data of SUMO inhibition are scarce. To date, the SAE inhibitor TAK-981 shows the most promise for clinical purposes and is currently the only compound directly targeting SUMOylation that has progressed to clinical trials in patients (Table 3). 
Table 3. Ongoing clinical trials of SUMO E1 inhibitor TAK-981. Data collected from clinicaltrials.gov (2.8.2021). Abbreviations: NCT\# national clinical trial identifier number.

\begin{tabular}{|c|c|c|c|c|c|}
\hline Intervention & Condition & Status & $\begin{array}{l}\text { Estimated } \\
\text { Enrollment }\end{array}$ & Phase & NCT\# \\
\hline $\begin{array}{l}\text { TAK-981 and } \\
\text { Pembrolizumab }\end{array}$ & $\begin{array}{l}\text { Advanced or metastatic } \\
\text { solid tumors }\end{array}$ & Recruiting & 242 & $\mathrm{I} / \mathrm{II}$ & NCT04381650 \\
\hline $\begin{array}{l}\text { TAK-981 and } \\
\text { Mezagitamab and } \\
\text { Daratumumab/ } \\
\text { hyaluronidase-fihj }\end{array}$ & $\begin{array}{l}\text { Relapsed and/or } \\
\text { refractory multiple } \\
\text { myeloma }\end{array}$ & Recruiting & 81 & $\mathrm{I} / \mathrm{II}$ & NCT04776018 \\
\hline $\begin{array}{c}\text { TAK-981 and } \\
\text { Rituximab }\end{array}$ & Non-Hodgkin lymphoma & Recruiting & 130 & $\mathrm{I} / \mathrm{II}$ & NCT04074330 \\
\hline TAK-981 & $\begin{array}{c}\text { Advanced or metastatic } \\
\text { solid tumors, } \\
\text { Relapsed/refractory } \\
\text { Non-Hodgkin lymphomas }\end{array}$ & Recruiting & 202 & $\mathrm{I} / \mathrm{II}$ & NCT03648372 \\
\hline $\begin{array}{c}\text { TAK-981 and } \\
\text { Cetuximab and Avelumab }\end{array}$ & Head and neck cancer & Recruiting & 12 & $0 / \mathrm{I}$ & NCT04065555 \\
\hline
\end{tabular}

A phase I/II study is evaluating the safety, tolerability, and preliminary efficacy of TAK-981 in combination with the immunotherapy drug pembrolizumab, in patients with advanced or metastatic solid tumors (ClinicalTrials.gov identifier: NCT04381650). Another phase I/II study is determining the safety and efficacy of TAK-981 in combination with anti-CD38 monoclonal antibodies, mezagitamab or daratumumab/hyaluronidase-fihj, for the treatment of patients with relapsed or refractory multiple myeloma (NCT04776018). The safety, tolerability, and efficacy of TAK-981 in combination with the anti-CD20 antibody rituximab, is evaluated in a phase I/II study of participants with CD20-positive non-Hodgkin lymphoma (NCT04074330). Furthermore, the safety, tolerability, and preliminary efficacy of TAK-981 as a monotherapy is evaluated a phase I/II study in participants with advanced or metastatic solid tumors or relapsed/refractory non-Hodgkin lymphomas (NCT03648372). In addition, an early phase I (phase 0) intratumoral microdosing study is investigating TAK-981's ability to activate innate immune effector cells within the tumor microenvironment in patients with localized or metastatic tumors of the head and neck (NCT04065555). The same study is also testing whether treatment with TAK-981 in combination with the immunotherapy drug avelumab or anti-EGFR antibody cetuximab, results in enhanced localized immune responses when compared to either immunotherapy alone.

Unfortunately, no other direct inhibitors of SUMO pathway components have progressed to clinical testing in patients. However, SENP1 is investigated as a potential therapeutic target in two observational ex vivo clinical trials. One study aims at determining the ability of a novel SENP1 inhibitor, senpPNA-R8, to silence SENP1 expression and penetrate into organotypic osteosarcoma cultures prepared from freshly collected patient samples (NCT03798587). Another prospective study is evaluating the expression levels of SENP1 in bone metastatic and non-metastatic mammary carcinomas to determine its potential use as a therapeutic target and prognostic marker in breast cancer (NCT04167605).

\subsection{Potential Rational Combinations}

Given the role of SUMO in anti-tumor immunity, TAK-981 is currently being evaluated in combination with immunotherapy drugs in clinical trials. Dysregulation of SUMO pathway can also promote resistance towards several anti-cancer drugs, such as the proteasome inhibitor bortezomib in $\mathrm{MM}$, anti-estrogens in breast cancer and different chemotherapeutics. Docetaxel resistance in PCa can be triggered via overexpression of the SENP1-HK2 axis or overexpression of PIAS1, further emphasizing heterogeneity of SUMO-dysregulation in cancer $[239,303]$. Hypoxia-induced SUMOylation of self-renewal 
and pluripotency regulator OCT4 decreases its level in embryonal carcinoma cells and promotes cisplatin and bleomycin resistance that can be counteracted with the induction of SENP1 overexpression [304]. Furthermore, SENP1-mediated deSUMOylation and the activation of janus kinase 2 (JAK2) promotes platinum resistance in ovarian cancer, which can be overcome by pharmacological inhibition of SENP1 that sensitizes cancer cells to cisplatin [305]. Thus, the combining of SUMO pathway inhibitors with already-established chemotherapy drugs and other anti-cancer agents may result in the improved targeting of specific cancer types through drug synergism and combat resistance.

\section{Conclusions and Future Perspectives}

Accumulating evidence strongly implicates a central role for SUMOylation in some cancer types as described earlier in detail. Intriguingly, the inhibition of SUMOylation may also be a novel way to activate the immune response to fight cancer cells, making the pharmacological inhibition of SUMOylation an attractive therapeutic strategy for the treatment of cancer patients. In the future, more sophisticated preclinical models of different contexts-also with an intact tumor microenvironment-are needed to fully characterize the biological significance of the SUMO pathway in cancer and explore its full therapeutic potential. Moreover, more individualized analyses of pathway activity in cancer patients with different types of hematological malignancies and solid tumors are needed to reveal potential therapeutic vulnerabilities and characterize potentially important new substrates.

Given the reversible nature of SUMO modification, it is important to deeply consider the balance between the regulators of SUMOylation to understand the final net contribution to malignant phenotypes in different cancers. Possible hurdles include the SUMOylation-independent functions of E3 ligases or deSUMOylases that may complicate the interpretation of the data. SENPs are essential for the balance of SUMOylation and the deSUMOylation of substrates. Interestingly, the development of SENP inhibitors has yielded encouraging results, as several SENP inhibitors have been identified to date and show promising activity in preclinical experiments. However, no selective inhibitors of SENPs other than SENP1 and SENP2 or SUMO E3 ligation enzymes are currently available despite recent strides made in the development of SUMO pathway inhibitors, limiting the identification and validation of novel therapeutic strategies towards SUMO-dysregulated cancers. Thus, the development of selective novel SENP and SUMO E3 ligase inhibitors is required to unravel the full potential of targeting SUMO machinery in cancer treatments and would open many new avenues to be explored, for example by using patient-derived ex vivo tumor models in combination with SUMO-pathway activity measurements. Furthermore, bifunctional small molecules that induce proximity between target proteins may be developed to trigger proteasomal degradation of SUMO machinery components or SUMO modification of specific proteins [306].

More than 20 years of intensive basic research is finally beginning to bear fruit, as the first clinical trials are investigating the safety and activity of SUMO pathway inhibition in cancer patients. The results of the first clinical trials with SUMO pathway inhibition in cancer patients are awaited with great interest, and they will help set new directions for research in this field. Since its discovery, SUMO has now strongly moved to the forefront of translational cancer research.

Supplementary Materials: The following are available online at https: / www.mdpi.com/article/ 10.3390/cancers13174402/s1, Table S1: “Expression and prognostic significance of SUMO machinery components in cancer" and supplementary references.

Author Contributions: Writing-original draft preparation, A.K., V.K.O., M.S.; writing-review and editing, L.M.M., L.S., K.E.; visualization, A.K.; project administration, M.S. All authors have read and agreed to the published version of the manuscript.

Funding: This research received no external funding.

Conflicts of Interest: The authors declare no conflict of interest. 


\section{References}

1. Sung, H.; Ferlay, J.; Siegel, R.L.; Laversanne, M.; Soerjomataram, I.; Jemal, A.; Bray, F. Global Cancer Statistics 2020: GLOBOCAN Estimates of Incidence and Mortality Worldwide for 36 Cancers in 185 Countries. CA Cancer J. Clin. 2021, 71, 209-249. [CrossRef] [PubMed]

2. Hanahan, D.; Weinberg, R.A. Hallmarks of Cancer: The Next Generation. Cell 2011, 144, 646-674. [CrossRef] [PubMed]

3. Prabakaran, S.; Lippens, G.; Steen, H.; Gunawardena, J. Post-translational modification: Nature's escape from genetic imprisonment and the basis for dynamic information encoding. Wiley Interdiscip. Rev. Syst. Biol. Med. 2012, 4, 565-583. [CrossRef] [PubMed]

4. Conibear, A.C. Deciphering protein post-translational modifications using chemical biology tools. Nat. Rev. Chem. 2020, 4, 674-695. [CrossRef]

5. Chen, L.; Liu, S.; Tao, Y. Regulating tumor suppressor genes: Post-translational modifications. Signal Transduct. Target. Ther. 2020, 5, 90. [CrossRef] [PubMed]

6. Xue, X.; Zhang, X.; Sun, F.; Wang, J. Emerging Role of Protein Post-Translational Modification in the Potential Clinical Application of Cancer. Nano Life 2020, 10, 2040008. [CrossRef]

7. Zhou, L.; Jiang, Y.; Luo, Q.; Li, L.; Jia, L. Neddylation: A novel modulator of the tumor microenvironment. Mol. Cancer 2019, 18, 77. [CrossRef]

8. Deng, L.; Meng, T.; Chen, L.; Wei, W.; Wang, P. The role of ubiquitination in tumorigenesis and targeted drug discovery. Signal Transduct. Target. Ther. 2020, 5, 11. [CrossRef]

9. Celen, A.B.; Sahin, U. Sumoylation on its 25th anniversary: Mechanisms, pathology, and emerging concepts. FEBS J. 2020, 287, 3110-3140. [CrossRef]

10. Geiss-Friedlander, R.; Melchior, F. Concepts in sumoylation: A decade on. Nat. Rev. Mol. Cell Biol. 2007, 8, 947-956. [CrossRef]

11. Sundvall, M. Role of ubiquitin and SUMO in intracellular trafficking. Curr. Issues Mol. Biol. 2020, 35, 99-108. [CrossRef]

12. Psakhye, I.; Jentsch, S. Protein group modification and synergy in the SUMO pathway as exemplified in DNA repair. Cell 2012, 151, 807-820. [CrossRef] [PubMed]

13. Vijay-Kumar, S.; Bugg, C.E.; Cook, W.J. Structure of ubiquitin refined at 1.8 Å resolution. J. Mol. Biol. 1987, 194, 531-544. [CrossRef]

14. Bayer, P.; Arndt, A.; Metzger, S.; Mahajan, R.; Melchior, F.; Jaenicke, R.; Becker, J. Structure determination of the small ubiquitinrelated modifier SUMO-1. J. Mol. Biol. 1998, 280, 275-286. [CrossRef]

15. Guo, D.; Li, M.; Zhang, Y.; Yang, P.; Eckenrode, S.; Hopkins, D.; Zheng, W.; Purohit, S.; Podolsky, R.H.; Muir, A.; et al. A functional variant of SUMO4, a new IkB $\alpha$ modifier, is associated with type diabetes. Nat. Genet. 2004, 36, 837-841. [CrossRef] [PubMed]

16. Bohren, K.M.; Nadkarni, V.; Song, J.H.; Gabbay, K.H.; Owerbach, D. A M55V polymorphism in a novel SUMO gene (SUMO-4) differentially activates heat shock transcription factors and is associated with susceptibility to type I diabetes mellitus. J. Biol. Chem. 2004, 279, 27233-27238. [CrossRef]

17. Wang, L.; Wansleeben, C.; Zhao, S.; Miao, P.; Paschen, W.; Yang, W. SUMO 2 is essential while SUMO 3 is dispensable for mouse embryonic development. EMBO Rep. 2014, 15, 878-885. [CrossRef]

18. Liang, Y.C.; Lee, C.C.; Yao, Y.L.; Lai, C.C.; Schmitz, M.L.; Yang, W.M. SUMO5, a novel poly-SUMO isoform, regulates PML nuclear bodies. Sci. Rep. 2016, 6, 26509. [CrossRef] [PubMed]

19. Gareau, J.R.; Lima, C.D. The SUMO pathway: Emerging mechanisms that shape specificity, conjugation and recognition. Nat. Rev. Mol. Cell Biol. 2010, 11, 861-871. [CrossRef]

20. Hendriks, I.A.; D'Souza, R.C.J.; Yang, B.; Verlaan-De Vries, M.; Mann, M.; Vertegaal, A.C.O. Uncovering global SUMOylation signaling networks in a site-specific manner. Nat. Struct. Mol. Biol. 2014, 21, 927-936. [CrossRef]

21. Tammsalu, T.; Matic, I.; Jaffray, E.G.; Ibrahim, A.F.M.; Tatham, M.H.; Hay, R.T. Proteome-wide identification of SUMO2 modification sites. Sci. Signal. 2014, 7, rs2. [CrossRef]

22. Tatham, M.H.; Jaffray, E.; Vaughan, O.A.; Desterro, J.M.P.; Botting, C.H.; Naismith, J.H.; Hay, R.T. Polymeric Chains of SUMO-2 and SUMO-3 are Conjugated to Protein Substrates by SAE1/SAE2 and Ubc9. J. Biol. Chem. 2001, 276, 35368-35374. [CrossRef]

23. Matic, I.; van Hagen, M.; Schimmel, J.; Macek, B.; Ogg, S.C.; Tatham, M.H.; Hay, R.T.; Lamond, A.I.; Mann, M.; Vertegaal, A.C.O. In vivo identification of human small ubiquitin-like modifier polymerization sites by high accuracy mass spectrometry and an in vitro to in vivo strategy. Mol. Cell. Proteom. 2008, 7, 132-144. [CrossRef]

24. Song, J.; Durrin, L.K.; Wilkinson, T.A.; Krontiris, T.G.; Chen, Y. Identification of a SUMO-binding motif that recognizes SUMOmodified proteins. Proc. Natl. Acad. Sci. USA 2004, 101, 14373-14378. [CrossRef]

25. Hecker, C.M.; Rabiller, M.; Haglund, K.; Bayer, P.; Dikic, I. Specification of SUMO1- and SUMO2-interacting motifs. J. Biol. Chem. 2006, 281, 16117-16127. [CrossRef] [PubMed]

26. Kunz, K.; Piller, T.; Müller, S. SUMO-specific proteases and isopeptidases of the SENP family at a glance. J. Cell Sci. 2018, 131, jcs211904. [CrossRef] [PubMed]

27. Gan-Erdene, T.; Nagamalleswari, K.; Yin, L.; Wu, K.; Pan, Z.Q.; Wilkinson, K.D. Identification and characterization of DEN1, a deneddylase of the ULP family. J. Biol. Chem. 2003, 278, 28892-28900. [CrossRef] [PubMed]

28. Nayak, A.; Müller, S. SUMO-specific proteases/isopeptidases: SENPs and beyond. Genome Biol. 2014, 15, 422. [CrossRef] [PubMed] 
29. Johnson, E.S.; Schwienhorst, I.; Dohmen, R.J.; Blobel, G. The ubiquitin-like protein Smt3p is activated for conjugation to other proteins by an Aos1p/Uba2p heterodimer. EMBO J. 1997, 16, 5509-5519. [CrossRef] [PubMed]

30. Desterro, J.M.P.; Rodriguez, M.S.; Kemp, G.D.; Ronald, T.H. Identification of the enzyme required for activation of the small ubiquitin-like protein SUMO-1. J. Biol. Chem. 1999, 274, 10618-10624. [CrossRef] [PubMed]

31. Okuma, T.; Honda, R.; Ichikawa, G.; Tsumagari, N.; Yasuda, H. In vitro SUMO-1 modification requires two enzymatic steps, E1 and E2. Biochem. Biophys. Res. Commun. 1999, 254, 693-698. [CrossRef] [PubMed]

32. Rytinki, M.M.; Kaikkonen, S.; Pehkonen, P.; Jääskeläinen, T.; Palvimo, J.J. PIAS proteins: Pleiotropic interactors associated with SUMO. Cell. Mol. Life Sci. 2009, 66, 3029-3041. [CrossRef] [PubMed]

33. Rabellino, A.; Andreani, C.; Scaglioni, P.P. The Role of PIAS SUMO E3-Ligases in Cancer. Cancer Res. 2017, $77,1542-1547$. [CrossRef]

34. Pichler, A.; Gast, A.; Seeler, J.S.; Dejean, A.; Melchior, F. The nucleoporin RanBP2 has SUMO1 E3 ligase activity. Cell 2002, 108, 109-120. [CrossRef]

35. Cappadocia, L.; Pichler, A.; Lima, C.D. Structural basis for catalytic activation by the human ZNF451 SUMO E3 ligase. Nat. Struct. Mol. Biol. 2015, 22, 968-975. [CrossRef] [PubMed]

36. Kagey, M.H.; Melhuish, T.A.; Wotton, D. The polycomb protein Pc2 is a SUMO E3. Cell 2003, 113, 127-137. [CrossRef]

37. Chu, Y.; Yang, X. SUMO E3 ligase activity of TRIM proteins. Oncogene 2011, 30, 1108-1116. [CrossRef]

38. Li, M.; Xu, X.; Chang, C.W.; Liu, Y. TRIM28 functions as the SUMO E3 ligase for PCNA in prevention of transcription induced DNA breaks. Proc. Natl. Acad. Sci. USA 2020, 117, 23588-23596. [CrossRef]

39. Hietakangas, V.; Anckar, J.; Blomster, H.A.; Fujimoto, M.; Palvimo, J.J.; Nakai, A.; Sistonen, L. PDSM, a motif for phosphorylationdependent SUMO modification. Proc. Natl. Acad. Sci. USA 2006, 103, 45-50. [CrossRef]

40. Stabell, M.; Sæther, T.; Røhr, Å.K.; Gabrielsen, O.S.; Myklebost, O. Methylation-dependent SUMOylation of the architectural transcription factor HMGA2. Biochem. Biophys. Res. Commun. 2021, 552, 91-97. [CrossRef] [PubMed]

41. Anckar, J.; Sistonen, L. SUMO: Getting it on. Biochem. Soc. Trans. 2007, 35, 1409-1413. [CrossRef]

42. Nacerddine, K.; Lehembre, F.; Bhaumik, M.; Artus, J.; Cohen-Tannoudji, M.; Babinet, C.; Pandolfi, P.P.; Dejean, A. The SUMO pathway is essential for nuclear integrity and chromosome segregation in mice. Dev. Cell 2005, 9, 769-779. [CrossRef]

43. Zhang, F.-P.; Mikkonen, L.; Toppari, J.; Palvimo, J.J.; Thesleff, I.; Jänne, O.A. Sumo-1 Function Is Dispensable in Normal Mouse Development. Mol. Cell. Biol. 2008, 28, 5381-5390. [CrossRef] [PubMed]

44. Cheng, J.; Kang, X.; Zhang, S.; Yeh, E.T.H. SUMO-Specific Protease 1 Is Essential for Stabilization of HIF1 $\alpha$ during Hypoxia. Cell 2007, 131, 584-595. [CrossRef]

45. Chiu, S.Y.; Asai, N.; Costantini, F.; Hsu, W. SUMO-specific protease 2 is essential for modulating p53-mdm2 in development of trophoblast stem cell niches and lineages. PLoS Biol. 2008, 6, e310. [CrossRef] [PubMed]

46. Lao, Y.; Yang, K.; Wang, Z.; Sun, X.; Zou, Q.; Yu, X.; Cheng, J.; Tong, X.; Yeh, E.T.H.; Yang, J.; et al. DeSUMOylation of MKK7 kinase by the SUMO2/3 protease SENP3 potentiates lipopolysaccharide-induced inflammatory signaling in macrophages. J. Biol. Chem. 2018, 293, 3965-3980. [CrossRef] [PubMed]

47. Liu, B.; Mink, S.; Wong, K.A.; Stein, N.; Getman, C.; Dempsey, P.W.; Wu, H.; Shuai, K. PIAS1 selectively inhibits interferoninducible genes and is important in innate immunity. Nat. Immunol. 2004, 5, 891-898. [CrossRef] [PubMed]

48. Roth, W.; Sustmann, C.; Kieslinger, M.; Gilmozzi, A.; Irmer, D.; Kremmer, E.; Turck, C.; Grosschedl, R. PIASy-Deficient Mice Display Modest Defects in IFN and Wnt Signaling. J. Immunol. 2004, 173, 6189-6199. [CrossRef]

49. Santti, H.; Mikkonen, L.; Anand, A.; Hirvonen-Santti, S.; Toppari, J.; Panhuysen, M.; Vauti, F.; Perera, W.; Corte, G.; Wurst, W.; et al. Disruption of the murine PIASx gene results in reduced testis weight. J. Mol. Endocrinol. 2005, 34, 645-654. [CrossRef]

50. Campla, C.K.; Breit, H.; Dong, L.; Gumerson, J.D.; Roger, J.E.; Swaroop, A. Pias3 is necessary for dorso-ventral patterning and visual response of retinal cones but is not required for rod photoreceptor differentiation. Biol. Open 2017, 6, 881-890. [CrossRef]

51. Lee, J.S.; Chu, I.S.; Heo, J.; Calvisi, D.F.; Sun, Z.; Roskams, T.; Durnez, A.; Demetris, A.J.; Thorgeirsson, S.S. Classification and prediction of survival in hepatocellular carcinoma by gene expression profiling. Hepatology 2004, 40, 667-676. [CrossRef] [PubMed]

52. Shen, H.J.; Zhu, H.Y.; Yang, C.; Ji, F. SENP2 regulates hepatocellular carcinoma cell growth by modulating the stability of $\beta$-catenin. Asian Pac. J. Cancer Prev. 2012, 13, 3583-3587. [CrossRef]

53. Tan, M.Y.; Mu, X.Y.; Liu, B.; Wang, Y.; Bao, E.D.; Qiu, J.X.; Fan, Y. SUMO-specific protease 2 suppresses cell migration and invasion through inhibiting the expression of MMP13 in bladder cancer cells. Cell. Physiol. Biochem. 2013, 32, 542-548. [CrossRef]

54. Pei, H.; Chen, L.; Liao, Q.M.; Wang, K.J.; Chen, S.G.; Liu, Z.J.; Zhang, Z.C. Sumo-specific protease 2 (Senp2) functions as a tumosuppressor in osteosarcoma via sox9 degradation. Exp. Ther. Med. 2018, 16, 5359-5365. [CrossRef]

55. Chen, X.L.; Wang, S.F.; Liang, X.T.; Liang, H.X.; Wang, T.T.; Wu, S.Q.; Qiu, Z.J.; Zhan, R.; Xu, Z.S. SENP2 exerts an anti-tumor effect on chronic lymphocytic leukemia cells through the inhibition of the Notch and NF-kB signaling pathways. Int. J. Oncol. 2019, 54, 455-466. [CrossRef] [PubMed]

56. Xie, H.; Gu, Y.; Wang, W.; Wang, X.; Ye, X.; Xin, C.; Lu, M.; Reddy, B.A.; Shu, P. Silencing of SENP2 in Multiple Myeloma Induces Bortezomib Resistance by Activating NF-кB Through the Modulation of IkB $\alpha$ Sumoylation. Sci. Rep. 2020, 10, 766. [CrossRef]

57. Li, X.; Meng, Y. SUMOylation Regulator-Related Molecules Can Be Used as Prognostic Biomarkers for Glioblastoma. Front. Cell Dev. Biol. 2021, 9, 689. [CrossRef] 
58. Taheri, M.; Oskooei, V.K.; Ghafouri-Fard, S. Protein inhibitor of activated STAT genes are differentially expressed in breast tumor tissues. Pers. Med. 2019, 16, 277-285. [CrossRef]

59. Tuccilli, C.; Baldini, E.; Sorrenti, S.; Di Gioia, C.; Bosco, D.; Ascoli, V.; Mian, C.; Barollo, S.; Rendina, R.; Coccaro, C.; et al. Papillary thyroid cancer is characterized by altered expression of genes involved in the sumoylation process. J. Biol. Regul. Homeost. Agents 2015, 29, 655-662.

60. Wang, J.; Ni, J.; Yi, S.; Song, D.; Ding, M. Protein inhibitor of activated STAT x $\alpha$ depresses cyclin D and cyclin D kinase, and contributes to the inhibition of osteosarcoma cell progression. Mol. Med. Rep. 2016, 13, 1645-1652. [CrossRef]

61. Zeng, J.S.; Zhang, Z.D.; Pei, L.; Bai, Z.Z.; Yang, Y.; Yang, H.; Tian, Q.H. CBX4 exhibits oncogenic activities in breast cancer via Notch1 signaling. Int. J. Biochem. Cell Biol. 2018, 95, 1-8. [CrossRef] [PubMed]

62. Li, X.; Gou, J.; Li, H.; Yang, X. Bioinformatic analysis of the expression and prognostic value of chromobox family proteins in human breast cancer. Sci. Rep. 2020, 10, 17739. [CrossRef] [PubMed]

63. Alshareeda, A.T.; Negm, O.H.; Green, A.R.; Nolan, C.; Tighe, P.; Albarakati, N.; Sultana, R.; Madhusudan, S.; Ellis, I.O.; Rakha, E.A. SUMOylation proteins in breast cancer. Breast Cancer Res. Treat. 2014, 144, 519-530. [CrossRef]

64. Agboola, A.; Musa, A.; Banjo, A.; Ayoade, B.; Deji-Agboola, M.; Nolan, C.; Rakha, E.; Ellis, I.; Green, A. PIAS $\gamma$ expression in relation to clinicopathological, tumour factors and survival in indigenous black breast cancer women. J. Clin. Pathol. 2014, 67, 301-306. [CrossRef] [PubMed]

65. Dabir, S.; Kluge, A.; Kresak, A.; Yang, M.; Fu, P.; Groner, B.; Wildey, G.; Dowlati, A. Low PIAS3 expression in malignant mesothelioma is associated with increased STAT3 activation and poor patient survival. Clin. Cancer Res. 2014, 20, 5124-5132. [CrossRef] [PubMed]

66. Wu, G.; Xu, Y.; Ruan, N.; Li, J.; Lv, Q.; Zhang, Q.; Chen, Y.; Wang, Q.; Xia, Q.; Li, Q. Genetic alteration and clinical significance of sumoylation regulators in multiple cancer types. J. Cancer 2020, 11, 6823-6833. [CrossRef] [PubMed]

67. Yang, Y.; Liang, Z.; Xia, Z.; Wang, X.; Ma, Y.; Sheng, Z.; Gu, Q.; Shen, G.; Zhou, L.; Zhu, H.; et al. SAE1 promotes human glioma progression through activating AKT SUMOylation-mediated signaling pathways. Cell Commun. Signal. 2019, 17, 1-14. [CrossRef]

68. Li, J.; Xu, Y.; Long, X.D.; Wang, W.; Jiao, H.K.; Mei, Z.; Yin, Q.Q.; Ma, L.N.; Zhou, A.W.; Wang, L.S.; et al. Cbx4 governs HIF-1 $\alpha$ to potentiate angiogenesis of hepatocellular carcinoma by its SUMO E3 ligase activity. Cancer Cell 2014, 25, 118-131. [CrossRef]

69. Jiao, H.K.; Xu, Y.; Li, J.; Wang, W.; Mei, Z.; Long, X.D.; Chen, G.Q. Prognostic significance of Cbx4 expression and its beneficial effect for transarterial chemoembolization in hepatocellular carcinoma. Cell Death Dis. 2015, 6, e1689. [CrossRef]

70. Chanda, A.; Chan, A.; Deng, L.; Kornaga, E.N.; Enwere, E.K.; Morris, D.G.; Bonni, S. Identification of the SUMO E3 ligase PIAS1 as a potential survival biomarker in breast cancer. PLoS ONE 2017, 12, e0177639. [CrossRef] [PubMed]

71. Wang, B.; Tang, J.; Liao, D.; Wang, G.; Zhang, M.; Sang, Y.; Cao, J.; Wu, Y.; Zhang, R.; Li, S.; et al. Chromobox homolog 4 is correlated with prognosis and tumor cell growth in hepatocellular carcinoma. Ann. Surg. Oncol. 2013, 20, 684-692. [CrossRef]

72. Qian, J.; Luo, Y.; Gu, X.; Wang, X. Inhibition of SENP6-Induced Radiosensitization of Human Hepatocellular Carcinoma Cells by Blocking Radiation-Induced NF-kB Activation. Cancer Biother. Radiopharm. 2013, 28, 196-200. [CrossRef]

73. Stefanska, B.; Cheishvili, D.; Suderman, M.; Arakelian, A.; Huang, J.; Hallett, M.; Han, Z.G.; Al-Mahtab, M.; Akbar, S.M.F.; Khan, W.A.; et al. Genome-wide study of hypomethylated and induced genes in patients with liver cancer unravels novel anticancer targets. Clin. Cancer Res. 2014, 20, 3118-3132. [CrossRef]

74. Zhao, Z.; Tan, X.; Zhao, A.; Zhu, L.; Yin, B.; Yuan, J.; Qiang, B.; Peng, X. microRNA-214-mediated UBC9 expression in glioma. BMB Rep. 2012, 45, 641-646. [CrossRef] [PubMed]

75. Yang, H.; Tang, Y.; Guo, W.; Du, Y.; Wang, Y.; Li, P.; Zang, W.; Yin, X.; Wang, H.; Chu, H.; et al. Up-regulation of microRNA-138 induce radiosensitization in lung cancer cells. Tumor Biol. 2014, 35, 6557-6565. [CrossRef] [PubMed]

76. Wang, C.; Tao, W.; Ni, S.; Chen, Q.; Zhao, Z.; Ma, L.; Fu, Y.; Jiao, Z. Tumor-suppressive microRNA-145 induces growth arrest by targeting SENP1 in human prostate cancer cells. Cancer Sci. 2015, 106, 375-382. [CrossRef] [PubMed]

77. Zheng, C.; Li, J.; Wang, Q.; Liu, W.; Zhou, J.; Liu, R.; Zeng, Q.; Peng, X.; Huang, C.; Cao, P.; et al. MicroRNA-195 functions as a tumor suppressor by inhibiting CBX4 in hepatocellular carcinoma. Oncol. Rep. 2015, 33, 1115-1122. [CrossRef] [PubMed]

78. Chen, Y.; Du, J.; Wang, Y.; Shi, H.; Jiang, Q.; Wang, Y.; Zhang, H.; Wei, Y.; Xue, W.; Pu, Z.; et al. MicroRNA-497-5p induces cell cycle arrest of cervical cancer cells in s phase by targeting cbx4. Onco-Targets Ther. 2019, 12, 10535-10545. [CrossRef]

79. Jiang, M.; Zhang, W.; Zhang, R.; Liu, P.; Ye, Y.; Yu, W.; Guo, X.; Yu, J. Cancer exosome-derived miR-9 and miR-181a promote the development of early-stage MDSCs via interfering with SOCS3 and PIAS3 respectively in breast cancer. Oncogene 2020, 39, 4681-4694. [CrossRef] [PubMed]

80. Kluge, A.; Dabir, S.; Vlassenbroeck, I.; Eisenberg, R.; Dowlati, A. Protein inhibitor of activated STAT3 expression in lung cancer. Mol. Oncol. 2011, 5, 256-264. [CrossRef]

81. Brantley, E.C.; Nabors, L.B.; Gillespie, G.Y.; Choi, Y.H.; Palmer, C.A.; Harrison, K.; Roarty, K.; Benveniste, E.N. Loss of protein inhibitors of activated STAT-3 expression in glioblastoma multiforme tumors: Implications for STAT-3 activation and gene expression. Clin. Cancer Res. 2008, 14, 4694-4704. [CrossRef] [PubMed]

82. Huang, C.; Han, Y.; Wang, Y.; Sun, X.; Yan, S.; Yeh, E.T.H.; Chen, Y.; Cang, H.; Li, H.; Shi, G.; et al. SENP3 is responsible for HIF-1 transactivation under mild oxidative stress via p300 de-SUMOylation. EMBO J. 2009, 28, 2748-2762. [CrossRef] [PubMed]

83. Zhou, Z.; Wang, M.; Li, J.; Xiao, M.; Chin, Y.E.; Cheng, J.; Yeh, E.T.H.; Yang, J.; Yi, J. SUMOylation and SENP3 regulate STAT3 activation in head and neck cancer. Oncogene 2016, 35, 5826-5838. [CrossRef] [PubMed] 
84. Kunz, K.; Wagner, K.; Mendler, L.; Hölper, S.; Dehne, N.; Müller, S. SUMO Signaling by Hypoxic Inactivation of SUMO-Specific Isopeptidases. Cell Rep. 2016, 16, 3075-3086. [CrossRef]

85. Kang, X.; Li, J.; Zou, Y.; Yi, J.; Zhang, H.; Cao, M.; Yeh, E.T.H.; Cheng, J. PIASy stimulates HIF1 $\alpha$ SUMOylation and negatively regulates HIF1 $\alpha$ activity in response to hypoxia. Oncogene 2010, 29, 5568-5578. [CrossRef] [PubMed]

86. Dünnebier, T.; Bermejo, J.L.; Haas, S.; Fischer, H.P.; Pierl, C.B.; Justenhoven, C.; Brauch, H.; Baisch, C.; Gilbert, M.; Harth, V.; et al. Common variants in the UBC9 gene encoding the SUMO-conjugating enzyme are associated with breast tumor grade. Int. J. Cancer 2009, 125, 596-602. [CrossRef]

87. Dünnebier, T.; Bermejo, J.L.; Haas, S.; Fischer, H.P.; Pierl, C.B.; Justenhoven, C.; Brauch, H.; Baisch, C.; Gilbert, M.; Harth, V.; et al. Polymorphisms in the UBC9 and PIAS3 genes of the SUMO-conjugating system and breast cancer risk. Breast Cancer Res. Treat. 2010, 121, 185-194. [CrossRef]

88. Mirecka, A.; Morawiec, Z.; Wozniak, K. Genetic Polymorphism of SUMO-Specific Cysteine Proteases-SENP1 and SENP2 in Breast Cancer. Pathol. Oncol. Res. 2016, 22, 817-823. [CrossRef] [PubMed]

89. Luo, Y.; You, S.; Wang, J.; Fan, S.; Shi, J.; Peng, A.; Yu, T. Association between sumoylation-related gene rs77447679 polymorphism and risk of gastric cancer(GC) in a Chinese population. J. Cancer 2017, 8, 3226-3231. [CrossRef]

90. Murakami, H.; Arnheiter, H. Sumoylation modulates transcriptional activity of MITF in a promoter-specific manner. Pigment Cell Res. 2005, 18, 265-277. [CrossRef]

91. Bertolotto, C.; Lesueur, F.; Giuliano, S.; Strub, T.; De Lichy, M.; Bille, K.; Dessen, P.; D’Hayer, B.; Mohamdi, H.; Remenieras, A.; et al. A SUMOylation-defective MITF germline mutation predisposes to melanoma and renal carcinoma. Nature 2011, 480, 94-98. [CrossRef]

92. King, R.; Weilbaecher, K.N.; McGill, G.; Cooley, E.; Mihm, M.; Fisher, D.E. Microphthalmia transcription factor: A sensitive and specific melanocyte marker for melanoma diagnosis. Am. J. Pathol. 1999, 155, 731-738. [CrossRef]

93. Buscà, R.; Berra, E.; Gaggioli, C.; Khaled, M.; Bille, K.; Marchetti, B.; Thyss, R.; Fitsialos, G.; Larribère, L.; Bertolotto, C.; et al. Hypoxia-inducible factor $1 \alpha$ is a new target of microphthalmia- associated transcription factor (MITF) in melanoma cells. J. Cell Biol. 2005, 170, 49-59. [CrossRef]

94. Linehan, W.M.; Srinivasan, R.; Schmidt, L.S. The genetic basis of kidney cancer: A metabolic disease. Nat. Rev. Urol. 2010, 7, 277-285. [CrossRef]

95. Levin, N.A.; Bnorka, P.M.; Warnock, M.L.; Gray, J.W.; Christman, M.F. Identification of novel regions of altered DNA copy number in small cell lung tumors. Genes Chromosom. Cancer 1995, 13, 175-185. [CrossRef]

96. Wang, J.; Qian, J.; Hoeksema, M.D.; Zou, Y.; Espinosa, A.V.; Rahman, S.M.J.; Zhang, B.; Massion, P.P. Integrative genomics analysis identifies candidate drivers at 3q26-29 amplicon in squamous cell carcinoma of the lung. Clin. Cancer Res. 2013, 19, 5580-5590. [CrossRef]

97. Fields, A.P.; Justilien, V.; Murray, N.R. The chromosome 3q26 OncCassette: A multigenic driver of human cancer. Adv. Biol. Regul. 2016, 60, 47-63. [CrossRef]

98. La-Touche, S.; Lemetre, C.; Lambros, M.; Stankiewicz, E.; Ng, C.K.Y.; Weigelt, B.; Rajab, R.; Tinwell, B.; Corbishley, C.; Watkin, N.; et al. DNA Copy Number Aberrations, and Human Papillomavirus Status in Penile Carcinoma. Clinico-Pathological Correlations and Potential Driver Genes. PLoS ONE 2016, 11, e0146740. [CrossRef]

99. Constanzo, J.D.; Tang, K.J.; Rindhe, S.; Melegari, M.; Liu, H.; Tang, X.; Rodriguez-Canales, J.; Wistuba, I.; Scaglioni, P.P. PIAS1-FAK Interaction Promotes the Survival and Progression of Non-Small Cell Lung Cancer. Neoplasia 2016, 18, 282-293. [CrossRef] [PubMed]

100. Veltman, I.M.; Vreede, L.A.; Cheng, J.; Looijenga, L.H.J.; Janssen, B.; Schoenmakers, E.F.P.M.; Yeh, E.T.H.; van Kessel, A.G. Fusion of the SUMO/Sentrin-specific protease 1 gene SENP1 and the embryonic polarity-related mesoderm development gene MESDC2 in a patient with an infantile teratoma and a constitutional $t(12 ; 15)(q 13 ; q 25)$. Hum. Mol. Genet. 2005, 14, 1955-1963. [CrossRef]

101. Tagawa, H.; Miura, I.; Suzuki, R.; Suzuki, H.; Hosokawa, Y.; Seto, M. Molecular cytogenetic analysis of the breakpoint region at 6q21-22 in T-cell lymphoma/leukemia cell lines. Genes Chromosom. Cancer 2002, 34, 175-185. [CrossRef]

102. Xu, H.D.; Shi, S.P.; Chen, X.; Qiu, J.D. Systematic analysis of the genetic variability that impacts sumo conjugation and their involvement in human diseases. Sci. Rep. 2015, 5, 10900. [CrossRef] [PubMed]

103. Chen, L.; Miao, Y.; Liu, M.; Zeng, Y.; Gao, Z.; Peng, D.; Hu, B.; Li, X.; Zheng, Y.; Xue, Y.; et al. Pan-cancer analysis reveals the functional importance of protein lysine modification in cancer development. Front. Genet. 2018, 9, 254. [CrossRef] [PubMed]

104. Kessler, J.D.; Kahle, K.T.; Sun, T.; Meerbrey, K.L.; Schlabach, M.R.; Schmitt, E.M.; Skinner, S.O.; Xu, Q.; Li, M.Z.; Hartman, Z.C.; et al. A SUMOylation-dependent transcriptional subprogram is required for Myc-driven tumorigenesis. Science 2012, 335, 348-353. [CrossRef]

105. González-Prieto, R.; Cuijpers, S.A.G.; Kumar, R.; Hendriks, I.A.; Vertegaal, A.C.O. c-Myc is targeted to the proteasome for degradation in a SUMOylation-dependent manner, regulated by PIAS1, SENP7 and RNF4. Cell Cycle 2015, 14, 1859-1872. [CrossRef]

106. Rabellino, A.; Melegari, M.; Tompkins, V.S.; Chen, W.; Van Ness, B.G.; Teruya-Feldstein, J.; Conacci-Sorrell, M.; Janz, S.; Scaglioni, P.P. PIAS1 Promotes Lymphomagenesis through MYC Upregulation. Cell Rep. 2016, 15, 2266-2278. [CrossRef]

107. Sun, X.X.; Chen, Y.; Su, Y.; Wang, X.; Chauhan, K.M.; Liang, J.; Daniel, C.J.; Sears, R.C.; Dai, M.S. SUMO protease SENP1 deSUMOylates and stabilizes c-Myc. Proc. Natl. Acad. Sci. USA 2018, 115, 10983-10988. [CrossRef] 
108. Yu, B.; Swatkoski, S.; Holly, A.; Lee, L.C.; Giroux, V.; Lee, C.S.; Hsu, D.; Smith, J.L.; Yuen, G.; Yue, J.; et al. Oncogenesis driven by the Ras/Raf pathway requires the SUMO E2 ligase Ubc9. Proc. Natl. Acad. Sci. USA 2015, 112, E1724-E1733. [CrossRef]

109. Li, R.; Wei, J.; Jiang, C.; Liu, D.; Deng, L.; Zhang, K.; Wang, P. Akt SUMOylation regulates cell proliferation and tumorigenesis. Cancer Res. 2013, 73, 5742-5753. [CrossRef] [PubMed]

110. Yan, Y.; Ollila, S.; Wong, I.P.L.; Vallenius, T.; Palvimo, J.J.; Vaahtomeri, K.; Mäkelä, T.P. SUMOylation of AMPK $\alpha 1$ by PIAS4 specifically regulates mTORC1 signalling. Nat. Commun. 2015, 6, 8979. [CrossRef] [PubMed]

111. Bae, S.H.; Jeong, J.W.; Park, J.A.; Kim, S.H.; Bae, M.K.; Choi, S.J.; Kim, K.W. Sumoylation increases HIF-1 $\alpha$ stability and its transcriptional activity. Biochem. Biophys. Res. Commun. 2004, 324, 394-400. [CrossRef]

112. Carbia-Nagashima, A.; Gerez, J.; Perez-Castro, C.; Paez-Pereda, M.; Silberstein, S.; Stalla, G.K.; Holsboer, F.; Arzt, E. RSUME, a Small RWD-Containing Protein, Enhances SUMO Conjugation and Stabilizes HIF-1 $\alpha$ during Hypoxia. Cell 2007, 131, 309-323. [CrossRef]

113. Lee, M.H.; Mabb, A.M.; Gill, G.B.; Yeh, E.T.H.; Miyamoto, S. NF-kB Induction of the SUMO Protease SENP2: A Negative Feedback Loop to Attenuate Cell Survival Response to Genotoxic Stress. Mol. Cell 2011, 43, 180-191. [CrossRef]

114. Choi, H.K.; Choi, K.C.; Yoo, J.Y.; Song, M.; Ko, S.J.; Kim, C.H.; Ahn, J.H.; Chun, K.H.; Yook, J.I.; Yoon, H.G. Reversible SUMOylation of TBL1-TBLR1 Regulates $\beta$-Catenin-Mediated Wnt Signaling. Mol. Cell 2011, 43, 203-216. [CrossRef]

115. Sharma, P.; Kuehn, M.R. SENP1-modulated sumoylation regulates retinoblastoma protein (RB) and Lamin A/C interaction and stabilization. Oncogene 2016, 35, 6429-6438. [CrossRef]

116. Gostissa, M.; Hengstermann, A.; Fogal, V.; Sandy, P.; Schwarz, S.E.; Scheffner, M.; Del Sal, G. Activation of p53 by conjugation to the ubiquitin-like protein SUMO-1. EMBO J. 1999, 18, 6462-6471. [CrossRef]

117. Rodriguez, M.S.; Desterro, J.M.P.; Lain, S.; Midgley, C.A.; Lane, D.P.; Hay, R.T. SUMO-1 modification activates the transcriptional response of p53. EMBO J. 1999, 18, 6455-6461. [CrossRef]

118. Xirodimas, D.P.; Chisholm, J.; Desterro, J.M.; Lane, D.P.; Hay, R.T. P14ARF promotes accumulation of SUMO-1 conjugated (H)Mdm2. FEBS Lett. 2002, 528, 207-211. [CrossRef]

119. Chen, L.; Chen, J. MDM2-ARF complex regulates p53 sumoylation. Oncogene 2003, 22, 5348-5357. [CrossRef]

120. Jiang, M.; Chiu, S.Y.; Hsu, W. SUMO-specific protease 2 in Mdm2-mediated regulation of p53. Cell Death Differ. 2011, 18, 1005-1015. [CrossRef] [PubMed]

121. Lee, Y.-R.; Chen, M.; Pandolfi, P.P. The functions and regulation of the PTEN tumour suppressor: New modes and prospects. Nat. Rev. Mol. Cell Biol. 2018, 19, 547-562. [CrossRef] [PubMed]

122. Huang, J.; Yan, J.; Zhang, J.; Zhu, S.; Wang, Y.; Shi, T.; Zhu, C.; Chen, C.; Liu, X.; Cheng, J.; et al. SUMO1 modification of PTEN regulates tumorigenesis by controlling its association with the plasma membrane. Nat. Commun. 2012, 3, 911. [CrossRef] [PubMed]

123. Bassi, C.; Ho, J.; Srikumar, T.; Dowling, R.J.O.; Gorrini, C.; Miller, S.J.; Mak, T.W.; Neel, B.G.; Raught, B.; Stambolic, V. Nuclear PTEN controls DNA repair and sensitivity to genotoxic stress. Science 2013, 341, 395-399. [CrossRef] [PubMed]

124. Wang, W.; Chen, Y.; Wang, S.; Hu, N.; Cao, Z.; Wang, W.; Tong, T.; Zhang, X. PIASx $\alpha$ ligase enhances SUMO1 modification of PTEN Protein as a SUMO E3 Ligase. J. Biol. Chem. 2014, 289, 3217-3230. [CrossRef]

125. Galanty, Y.; Belotserkovskaya, R.; Coates, J.; Polo, S.; Miller, K.M.; Jackson, S.P. Mammalian SUMO E3-ligases PIAS1 and PIAS4 promote responses to DNA double-strand breaks. Nature 2009, 462, 935-939. [CrossRef]

126. Shim, H.S.; Wei, M.; Brandhorst, S.; Longo, V.D. Starvation promotes REV1 SUMOylation and p53-dependent sensitization of melanoma and breast cancer cells. Cancer Res. 2015, 75, 1056-1067. [CrossRef]

127. Niskanen, E.A.; Malinen, M.; Sutinen, P.; Toropainen, S.; Paakinaho, V.; Vihervaara, A.; Joutsen, J.; Kaikkonen, M.U.; Sistonen, L.; Palvimo, J.J. Global SUMOylation on active chromatin is an acute heat stress response restricting transcription. Genome Biol. 2015, 16, 153. [CrossRef]

128. Zhu, X.; Ding, S.; Qiu, C.; Shi, Y.; Song, L.; Wang, Y.; Wang, Y.; Li, J.; Wang, Y.; Sun, Y.; et al. SUMOylation negatively regulates angiogenesis by targeting endothelial NOTCH signaling. Circ. Res. 2017, 121, 636-649. [CrossRef]

129. Zhang, C.; Mukherjee, S.; Tucker-Burden, C.; Ross, J.L.; Chau, M.J.; Kong, J.; Brat, D.J. TRIM8 regulates stemness in glioblastoma through PIAS3-STAT3. Mol. Oncol. 2017, 11, 280-294. [CrossRef]

130. Hannoun, Z.; Maarifi, G.; Chelbi-Alix, M.K. The implication of SUMO in intrinsic and innate immunity. Cytokine Growth Factor Rev. 2016, 29, 3-16. [CrossRef] [PubMed]

131. Garvin, A.J.; Densham, R.M.; Blair-Reid, S.A.; Pratt, K.M.; Stone, H.R.; Weekes, D.; Lawrence, K.J.; Morris, J.R. The deSUMOylase SENP7 promotes chromatin relaxation for homologous recombination DNA repair. EMBO Rep. 2013, 14, 975-983. [CrossRef]

132. Wagner, K.; Kunz, K.; Piller, T.; Tascher, G.; Hölper, S.; Stehmeier, P.; Keiten-Schmitz, J.; Schick, M.; Keller, U.; Müller, S. The SUMO Isopeptidase SENP6 Functions as a Rheostat of Chromatin Residency in Genome Maintenance and Chromosome Dynamics. Cell Rep. 2019, 29, 480-494.e5. [CrossRef]

133. Garvin, A.J.; Walker, A.K.; Densham, R.M.; Chauhan, A.S.; Stone, H.R.; Mackay, H.L.; Jamshad, M.; Starowicz, K.; Daza-Martin, M.; Ronson, G.E.; et al. The deSUMOylase SENP2 coordinates homologous recombination and nonhomologous end joining by independent mechanisms. Genes Dev. 2019, 33, 333-347. [CrossRef]

134. Despras, E.; Sittewelle, M.; Pouvelle, C.; Delrieu, N.; Cordonnier, A.M.; Kannouche, P.L. Rad18-dependent SUMOylation of human specialized DNA polymerase eta is required to prevent under-replicated DNA. Nat. Commun. 2016, 7, 13326. [CrossRef]

135. Ryu, H.-Y.; Hochstrasser, M. Histone sumoylation and chromatin dynamics. Nucleic Acids Res. 2021, 49, 6043-6052. [CrossRef] 
136. Lee, B.; Muller, M.T. SUMOylation enhances DNA methyltransferase 1 activity. Biochem. J. 2009, 421, 449-461. [CrossRef] [PubMed]

137. Nayak, A.; Viale-Bouroncle, S.; Morsczeck, C.; Muller, S. The SUMO-specific isopeptidase SENP3 regulates MLL1/MLL2 methyltransferase complexes and controls osteogenic differentiation. Mol. Cell 2014, 55, 47-58. [CrossRef] [PubMed]

138. Srinivasan, S.; Shankar, S.R.; Wang, Y.; Taneja, R. SUMOylation of G9a regulates its function as an activator of myoblast proliferation. Cell Death Dis. 2019, 10, 250. [CrossRef] [PubMed]

139. Liu, B.; Tahk, S.; Yee, K.M.; Fan, G.; Shuai, K. The ligase PIAS1 restricts natural regulatory T cell differentiation by epigenetic repression. Science 2010, 330, 521-525. [CrossRef]

140. Liu, B.; Tahk, S.; Yee, K.M.; Yang, R.; Yang, Y.; Mackie, R.; Hsu, C.; Chernishof, V.; O’Brien, N.; Jin, Y.; et al. PIAS1 regulates breast tumorigenesis through selective epigenetic gene silencing. PLoS ONE 2014, 9, e89464. [CrossRef] [PubMed]

141. Bawa-Khalfe, T.; Cheng, J.; Lin, S.H.; Ittmann, M.M.; Yeh, E.T.H. SENP1 induces prostatic intraepithelial neoplasia through multiple mechanisms. J. Biol. Chem. 2010, 285, 25859-25866. [CrossRef]

142. Wang, Q.; Xia, N.; Li, T.; Xu, Y.; Zou, Y.; Zuo, Y.; Fan, Q.; Bawa-Khalfe, T.; Yeh, E.T.H.; Cheng, J. SUMO-specific protease 1 promotes prostate cancer progression and metastasis. Oncogene 2013, 32, 2493-2498. [CrossRef]

143. Castillo-Lluva, S.; Tatham, M.H.; Jones, R.C.; Jaffray, E.G.; Edmondson, R.D.; Hay, R.T.; Malliri, A. SUMOylation of the GTPase Rac1 is required for optimal cell migration. Nat. Cell Biol. 2010, 12, 1078-1085. [CrossRef]

144. Li, C.; McManus, F.P.; Plutoni, C.; Pascariu, C.M.; Nelson, T.; Alberici Delsin, L.E.; Emery, G.; Thibault, P. Quantitative SUMO proteomics identifies PIAS1 substrates involved in cell migration and motility. Nat. Commun. 2020, 11, 834. [CrossRef]

145. Long, J.; Matsuura, I.; He, D.; Wang, G.; Shuai, K.; Liu, F. Repression of Smad transcriptional activity by PIASy, an inhibitor of activated STAT. Proc. Natl. Acad. Sci. USA 2003, 100, 9791-9796. [CrossRef]

146. Chandhoke, A.S.; Karve, K.; Dadakhujaev, S.; Netherton, S.; Deng, L.; Bonni, S. The ubiquitin ligase Smurf2 suppresses TGF $\beta$ induced epithelial-mesenchymal transition in a sumoylation-regulated manner. Cell Death Differ. 2016, 23, 876-888. [CrossRef]

147. Jang, D.; Kwon, H.; Choi, M.; Lee, J.; Pak, Y. Sumoylation of Flotillin-1 promotes EMT in metastatic prostate cancer by suppressing Snail degradation. Oncogene 2019, 38, 3248-3260. [CrossRef]

148. Chanda, A.; Ikeuchi, Y.; Karve, K.; Sarkar, A.; Chandhoke, A.S.; Deng, L.; Bonni, A.; Bonni, S. PIAS1 and TIF1 $\gamma$ collaborate to promote SnoN SUMOylation and suppression of epithelial-mesenchymal transition. Cell Death Differ. 2021, 28, 267-282. [CrossRef]

149. Jiao, J.; Zhang, R.; Li, Z.; Yin, Y.; Fang, X.; Ding, X.; Cai, Y.; Yang, S.; Mu, H.; Zong, D.; et al. Nuclear Smad6 promotes gliomagenesis by negatively regulating PIAS3-mediated STAT3 inhibition. Nat. Commun. 2018, 9, 2504. [CrossRef]

150. Adorisio, S.; Fierabracci, A.; Muscari, I.; Liberati, A.M.; Ayroldi, E.; Migliorati, G.; Thuy, T.T.; Riccardi, C.; Delfino, D.V. SUMO proteins: Guardians of immune system. J. Autoimmun. 2017, 84, 21-28. [CrossRef]

151. Ran, Y.; Liu, T.-T.; Zhou, Q.; Li, S.; Mao, A.-P.; Li, Y.; Liu, L.-J.; Cheng, J.-K.; Shu, H.-B. SENP2 negatively regulates cellular antiviral response by deSUMOylating IRF3 and conditioning it for ubiquitination and degradation. J. Mol. Cell Biol. 2011, 3, 283-292. [CrossRef] [PubMed]

152. Liang, Q.; Deng, H.; Li, X.; Wu, X.; Tang, Q.; Chang, T.-H.; Peng, H.; Rauscher, F.J.; Ozato, K.; Zhu, F. Tripartite Motif-Containing Protein 28 Is a Small Ubiquitin-Related Modifier E3 Ligase and Negative Regulator of IFN Regulatory Factor 7. J. Immunol. 2011, 187, 4754-4763. [CrossRef] [PubMed]

153. Kubota, T.; Matsuoka, M.; Xu, S.; Otsuki, N.; Takeda, M.; Kato, A.; Ozato, K. PIASy inhibits virus-induced and interferonstimulated transcription through distinct mechanisms. J. Biol. Chem. 2011, 286, 8165-8175. [CrossRef] [PubMed]

154. Chang, T.-H.; Xu, S.; Tailor, P.; Kanno, T.; Ozato, K. The Small Ubiquitin-like Modifier-Deconjugating Enzyme Sentrin-Specific Peptidase 1 Switches IFN Regulatory Factor 8 from a Repressor to an Activator during Macrophage Activation. J. Immunol. 2012, 189, 3548-3556. [CrossRef]

155. Kubota, T.; Matsuoka, M.; Chang, T.H.; Tailor, P.; Sasaki, T.; Tashiro, M.; Kato, A.; Ozato, K. Virus infection triggers SUMOylation of IRF3 and IRF7, leading to the negative regulation of type I interferon gene expression. J. Biol. Chem. 2008, 283, 25660-25670. [CrossRef]

156. Hu, M.M.; Yang, Q.; Xie, X.Q.; Liao, C.Y.; Lin, H.; Liu, T.T.; Yin, L.; Shu, H.B. Sumoylation Promotes the Stability of the DNA Sensor cGAS and the Adaptor STING to Regulate the Kinetics of Response to DNA Virus. Immunity 2016, 45, 555-569. [CrossRef]

157. Cui, Y.; Yu, H.; Zheng, X.; Peng, R.; Wang, Q.; Zhou, Y.; Wang, R.; Wang, J.; Qu, B.; Shen, N.; et al. SENP7 Potentiates cGAS Activation by Relieving SUMO-Mediated Inhibition of Cytosolic DNA Sensing. PLoS Pathog. 2017, 13, e1006156. [CrossRef]

158. Desterro, J.M.P.; Rodriguez, M.S.; Hay, R.T. SUMO-1 modification of IkB $\alpha$ inhibits NF-kB activation. Mol. Cell 1998, 2, $233-239$. [CrossRef]

159. Huang, T.T.; Wuerzberger-Davis, S.M.; Wu, Z.H.; Miyamoto, S. Sequential Modification of NEMO/IKK $\gamma$ by SUMO-1 and Ubiquitin Mediates NF-kB Activation by Genotoxic Stress. Cell 2003, 115, 565-576. [CrossRef]

160. Zhao, T.; Yang, L.; Sun, Q.; Arguello, M.; Ballard, D.W.; Hiscott, J.; Lin, R. The NEMO adaptor bridges the nuclear factor-kB and interferon regulatory factor signaling pathways. Nat. Immunol. 2007, 8, 592-600. [CrossRef]

161. Liu, X.; Chen, W.; Wang, Q.; Li, L.; Wang, C. Negative Regulation of TLR Inflammatory Signaling by the SUMO-deconjugating Enzyme SENP6. PLoS Pathog. 2013, 9, e1003480. [CrossRef]

162. Liu, X.; Wang, Q.; Chen, W.; Wang, C. Dynamic regulation of innate immunity by ubiquitin and ubiquitin-like proteins. Cytokine Growth Factor Rev. 2013, 24, 559-570. [CrossRef] 
163. Yu, X.; Lao, Y.; Teng, X.L.; Li, S.; Zhou, Y.; Wang, F.; Guo, X.; Deng, S.; Chang, Y.; Wu, X.; et al. SENP3 maintains the stability and function of regulatory T cells via BACH2 deSUMOylation. Nat. Commun. 2018, 9, 3157. [CrossRef]

164. Xiao, M.; Bian, Q.; Lao, Y.; Yi, J.; Sun, X.; Sun, X.; Yang, J. SENP3 loss promotes M2 macrophage polarization and breast cancer progression. Mol. Oncol. 2021. [CrossRef] [PubMed]

165. Hu, Z.; Teng, X.L.; Zhang, T.; Yu, X.; Ding, R.; Yi, J.; Deng, L.; Wang, Z.; Zou, Q. SENP3 senses oxidative stress to facilitate STING-dependent dendritic cell antitumor function. Mol. Cell 2021, 81, 940-952.e5. [CrossRef] [PubMed]

166. Decque, A.; Joffre, O.; Magalhaes, J.G.; Cossec, J.C.; Blecher-Gonen, R.; Lapaquette, P.; Silvin, A.; Manel, N.; Joubert, P.E.; Seeler, J.S.; et al. Sumoylation coordinates the repression of inflammatory and anti-viral gene-expression programs during innate sensing. Nat. Immunol. 2016, 17, 140-149. [CrossRef] [PubMed]

167. Crowl, J.T.; Stetson, D.B. SUMO2 and SUMO3 redundantly prevent a noncanonical type I interferon response. Proc. Natl. Acad. Sci. USA 2018, 115, 6798-6803. [CrossRef] [PubMed]

168. De Thé, H.; Chomienne, C.; Lanotte, M.; Degos, L.; Dejean, A. The t(15;17) translocation of acute promyelocytic leukaemia fuses the retinoic acid receptor $\alpha$ gene to a novel transcribed locus. Nature 1990, 347, 558-561. [CrossRef]

169. Longo, L.; Pandolfi, P.P.; Biondi, A.; Rambaldi, A.; Mencarelli, A.; Lo Coco, F.; Diverio, D.; Pegoraro, L.; Avanzi, G.; Tabilio, A.; et al. Rearrangements and aberrant expression of the retinoic acid receptor $\alpha$ gene in acute promyelocytic leukemias. J. Exp. Med. 1990, 172, 1571-1575. [CrossRef]

170. Kakizuka, A.; Miller, W.H.; Umesono, K.; Warrell, R.P.; Frankel, S.R.; Murty, V.V.V.S.; Dmitrovsky, E.; Evans, R.M. Chromosomal translocation $\mathrm{t}(15 ; 17)$ in human acute promyelocytic leukemia fuses RAR $\alpha$ with a novel putative transcription factor, PML. Cell 1991, 66, 663-674. [CrossRef]

171. De Thé, H.; Pandolfi, P.P.; Chen, Z. Acute Promyelocytic Leukemia: A Paradigm for Oncoprotein-Targeted Cure. Cancer Cell 2017, 32, 552-560. [CrossRef]

172. Daniel, M.; Koken, M.; Romagne, O.; Barbey, S.; Bazarbachi, A.; Stadler, M.; Guillemin, M.; Degos, L.; Chomienne, C.; de Thé, H. PML protein expression in hematopoietic and acute promyelocytic leukemia cells. Blood 1993, 82, 1858-1867. [CrossRef]

173. Zhong, S.; Müller, S.; Ronchetti, S.; Freemont, P.S.; Dejean, A.; Pandolfi, P.P. Role of SUMO-1-modified PML in nuclear body formation. Blood 2000, 95, 2748-2753. [CrossRef] [PubMed]

174. Van Damme, E.; Laukens, K.; Dang, T.H.; van Ostade, X. A Manually Curated Network of the PML Nuclear Body Interactome Reveals an Important Role for PML-NBs in SUMOylation dynamics. Int. J. Biol. Sci. 2010, 6, 51-67. [CrossRef]

175. Breitman, T.R.; Selonick, S.E.; Collins, S.J. Induction of differentiation of the human promyelocytic leukemia cell line (HL-60) by retinoic acid. Proc. Natl. Acad. Sci. USA 1980, 77, 2936-2940. [CrossRef]

176. Hong, S.H.; David, G.; Wong, C.W.; Dejean, A.; Privalsky, M.L. SMRT corepressor interacts with PLZF and with the PML-retinoic acid receptor $\alpha(\operatorname{RAR} \alpha)$ and PLZF-RAR $\alpha$ oncoproteins associated with acute promyelocytic leukemia. Proc. Natl. Acad. Sci. USA 1997, 94, 9028-9033. [CrossRef] [PubMed]

177. Lin, R.J.; Evans, R.M. Acquisition of oncogenic potential by RAR chimeras in acute promyelocytic leukemia through formation of homodimers. Mol. Cell 2000, 5, 821-830. [CrossRef]

178. Zhu, J.; Zhou, J.; Peres, L.; Riaucoux, F.; Honoré, N.; Kogan, S.; De Thé, H. A sumoylation site in PML/RARA is essential for leukemic transformation. Cancer Cell 2005, 7, 143-153. [CrossRef]

179. Breitman, T.; Collins, S.; Keene, B. Terminal differentiation of human promyelocytic leukemic cells in primary culture in response to retinoic acid. Blood 1981, 57, 1000-1004. [CrossRef]

180. Lallemand-Breitenbach, V.; Guillemin, M.C.; Janin, A.; Daniel, M.T.; Degos, L.; Kogan, S.C.; Bishop, J.M.; De Thé, H. Retinoic acid and arsenic synergize to eradicate leukemic cells in a mouse model of acute promyelocytic leukemia. J. Exp. Med. 1999, 189, 1043-1052. [CrossRef]

181. Ablain, J.; Leiva, M.; Peres, L.; Fonsart, J.; Anthony, E.; De Thé, H. Uncoupling RARA transcriptional activation and degradation clarifies the bases for APL response to therapies. J. Exp. Med. 2013, 210, 647-653. [CrossRef]

182. Lallemand-Breitenbach, V.; Jeanne, M.; Benhenda, S.; Nasr, R.; Lei, M.; Peres, L.; Zhou, J.; Raught, B.; de Thé, H. Arsenic degrades PML or PML-RAR $\alpha$ through a SUMO-triggered RNF4/ubiquitin-mediated pathway. Nat. Cell Biol. 2008, 10, 547-555. [CrossRef]

183. Fasci, D.; Anania, V.G.; Lill, J.R.; Salvesen, G.S. SUMO deconjugation is required for arsenic-triggered ubiquitylation of PML. Sci. Signal. 2015, 8, ra56. [CrossRef]

184. Van Gils, N.; Verhagen, H.J.M.P.; Smit, L. Reprogramming acute myeloid leukemia into sensitivity for retinoic-acid-driven differentiation. Exp. Hematol. 2017, 52, 12-23. [CrossRef]

185. Baik, H.; Boulanger, M.; Hosseini, M.; Kowalczyk, J.; Zaghdoudi, S.; Salem, T.; Sarry, J.E.; Hicheri, Y.; Cartron, G.; Piechaczyk, M.; et al. Targeting the sumo pathway primes all-trans retinoic acid-induced differentiation of nonpromyelocytic acute myeloid leukemias. Cancer Res. 2018, 78, 2601-2613. [CrossRef]

186. Zhou, P.; Chen, X.; Li, M.; Tan, J.; Zhang, Y.; Yuan, W.; Zhou, J.; Wang, G. 2-D08 as a SUMOylation inhibitor induced ROS accumulation mediates apoptosis of acute myeloid leukemia cells possibly through the deSUMOylation of NOX2. Biochem. Biophys. Res. Commun. 2019, 513, 1063-1069. [CrossRef]

187. Xu, R.; Yu, S.; Zhu, D.; Huang, X.; Xu, Y.; Lao, Y.; Tian, Y.; Zhang, J.; Tang, Z.; Zhang, Z.; et al. hCINAP regulates the DNA-damage response and mediates the resistance of acute myelocytic leukemia cells to therapy. Nat. Commun. 2019, 10, 3812. [CrossRef] [PubMed]

188. Döhner, H.; Weisdorf, D.J.; Bloomfield, C.D. Acute Myeloid Leukemia. N. Engl. J. Med. 2015, 373, 1136-1152. [CrossRef] 
189. Mendez, L.M.; Posey, R.R.; Pandolfi, P.P. The Interplay Between the Genetic and Immune Landscapes of AML: Mechanisms and Implications for Risk Stratification and Therapy. Front. Oncol. 2019, 9, 1162. [CrossRef]

190. Haindl, M.; Harasim, T.; Eick, D.; Muller, S. The nucleolar SUMO-specific protease SENP3 reverses SUMO modification of nucleophosmin and is required for rRNA processing. EMBO Rep. 2008, 9, 273-279. [CrossRef] [PubMed]

191. Hoellein, A.; Fallahi, M.; Schoeffmann, S.; Steidle, S.; Schaub, F.X.; Rudelius, M.; Laitinen, I.; Nilsson, L.; Goga, A.; Peschel, C.; et al. Myc-induced SUMOylation is a therapeutic vulnerability for B-cell lymphoma. Blood 2014, 124, 2081-2090. [CrossRef] [PubMed]

192. Vishwamitra, D.; Curry, C.V.; Shi, P.; Alkan, S.; Amin, H.M. SUMOylation Confers Posttranslational Stability on NPM-ALK Oncogenic Protein. Neoplasia 2015, 17, 742-754. [CrossRef]

193. Van de Donk, N.W.C.J.; Pawlyn, C.; Yong, K.L. Multiple myeloma. Lancet 2021, 397, 410-427. [CrossRef]

194. Driscoll, J.J.; Pelluru, D.; Lefkimmiatis, K.; Fulciniti, M.; Prabhala, R.H.; Greipp, P.R.; Barlogie, B.; Tai, Y.T.; Anderson, K.C.; Shaughnessy, J.D.; et al. The sumoylation pathway is dysregulated in multiple myeloma and is associated with adverse patient outcome. Blood 2010, 115, 2827-2834. [CrossRef]

195. Xu, J.; Sun, H.Y.; Xiao, F.J.; Wang, H.; Yang, Y.; Wang, L.; Gao, C.J.; Guo, Z.K.; Wu, C.T.; Wang, L.S. SENP1 inhibition induces apoptosis and growth arrest of multiple myeloma cells through modulation of NF-kB signaling. Biochem. Biophys. Res. Commun. 2015, 460, 409-415. [CrossRef]

196. Rizos, H.; Woodruff, S.; Kefford, R.F. p14ARF interacts with the SUMO-conjugating enzyme Ubc9 and promotes the sumoylation of its binding partners. Cell Cycle 2005, 4, 590-596. [CrossRef]

197. Tago, K.; Chiocca, S.; Sherr, C.J. Sumoylation induced by the Arf tumor suppressor: A p53-independent function. Proc. Natl. Acad. Sci. USA 2005, 102, 7689-7694. [CrossRef]

198. Kawano, M.; Hirano, T.; Matsuda, T.; Taga, T.; Horii, Y.; Iwato, K.; Asaoku, H.; Tang, B.; Tanabe, O.; Tanaka, H.; et al. Autocrine generation and requirement of BSF-2/IL-6 for human multiple myelomas. Nature 1988, 332, 83-85. [CrossRef]

199. Klein, B.; Zhang, X.; Jourdan, M.; Content, J.; Houssiau, F.; Aarden, L.; Piechaczyk, M.; Bataille, R. Paracrine rather than autocrine regulation of myeloma-cell growth and differentiation by interleukin-6. Blood 1989, 73, 517-526. [CrossRef]

200. Bommert, K.; Bargou, R.C.; Stühmer, T. Signalling and survival pathways in multiple myeloma. Eur. J. Cancer 2006, 42, 1574-1580. [CrossRef]

201. Bawa-Khalfe, T.; Lu, L.S.; Zuo, Y.; Huang, C.; Dere, R.; Lin, F.M.; Yeh, E.T.H. Differential expression of SUMO-specific protease 7 variants regulates epithelial-mesenchymal transition. Proc. Natl. Acad. Sci. USA 2012, 109, 17466-17471. [CrossRef]

202. Cashman, R.; Cohen, H.; Ben-Hamo, R.; Zilberberg, A.; Efroni, S. SENP5 mediates breast cancer invasion via a TGFßRI SUMOylation cascade. Oncotarget 2014, 5, 1071-1082. [CrossRef] [PubMed]

203. Chandhoke, A.S.; Chanda, A.; Karve, K.; Deng, L.; Bonni, S. The PIAS3-Smurf2 sumoylation pathway suppresses breast cancer organoid invasiveness. Oncotarget 2017, 8, 21001-21014. [CrossRef]

204. Sentis, S.; Le Romancer, M.; Bianchin, C.; Rostan, M.-C.; Corbo, L. Sumoylation of the Estrogen Receptor $\alpha$ Hinge Region Regulates Its Transcriptional Activity. Mol. Endocrinol. 2005, 19, 2671-2684. [CrossRef]

205. Lee, J.Y.; Won, H.Y.; Park, J.H.; Kim, H.Y.; Choi, H.J.; Shin, D.H.; Kang, J.H.; Woo, J.K.; Oh, S.H.; Son, T.; et al. MEL-18 loss mediates estrogen receptor- $\alpha$ downregulation and hormone independence. J. Clin. Investig. 2015, 125, 1801-1814. [CrossRef] [PubMed]

206. Traboulsi, T.; El Ezzy, M.; Dumeaux, V.; Audemard, E.; Mader, S. Role of SUMOylation in differential ER $\alpha$ transcriptional repression by tamoxifen and fulvestrant in breast cancer cells. Oncogene 2019, 38, 1019-1037. [CrossRef]

207. Park, Y.Y.; Kim, K.; Kim, S.B.; Hennessy, B.T.; Kim, S.M.; Park, E.S.; Lim, J.Y.; Li, J.; Lu, Y.; Gonzalez-Angulo, A.M.; et al. Reconstruction of nuclear receptor network reveals that NR2E3 is a novel upstream regulator of ESR1 in breast cancer. EMBO Mol. Med. 2012, 4, 52-67. [CrossRef]

208. Yang, S.-F.; Hou, M.-F.; Chen, F.-M.; Ou-Yang, F.; Wu, Y.-C.; Chai, C.-Y.; Yeh, Y.-T. Prognostic value of protein inhibitor of activated STAT3 in breast cancer patients receiving hormone therapy. BMC Cancer 2016, 16, 20. [CrossRef]

209. Sundvall, M.; Korhonen, A.; Vaparanta, K.; Anckar, J.; Halkilahti, K.; Salah, Z.; Aqeilan, R.I.; Palvimo, J.J.; Sistonen, L.; Elenius, K. Protein inhibitor of activated STAT3 (PIAS3) protein promotes SUMOylation and nuclear sequestration of the intracellular domain of ErbB4 protein. J. Biol. Chem. 2012, 287, 23216-23226. [CrossRef]

210. Knittle, A.M.; Helkkula, M.; Johnson, M.S.; Sundvall, M.; Elenius, K. SUMOylation regulates nuclear accumulation and signaling activity of the soluble intracellular domain of the ErbB4 receptor tyrosine kinase. J. Biol. Chem. 2017, 292, 19890-19904. [CrossRef]

211. Ni, C.Y.; Murphy, M.P.; Golde, T.E.; Carpenter, G. $\gamma$-secretase cleavage and nuclear locatization of ErbB-4 receptor tyrosine kinase. Science 2001, 294, 2179-2181. [CrossRef]

212. Määttä, J.A.; Sundvall, M.; Junttila, T.T.; Peri, L.; Laine, V.J.O.; Isola, J.; Egeblad, M.; Elenius, K. Proteolytic cleavage and phosphorylation of a tumor-associated ErbB4 isoform promote ligand-independent survival and cancer cell growth. Mol. Biol. Cell 2006, 17, 67-79. [CrossRef]

213. Junttila, T.T.; Sundvall, M.; Lundin, M.; Lundin, J.; Tanner, M.; Härkönen, P.; Joensuu, H.; Isola, J.; Elenius, K. Cleavable ErbB4 isoform in estrogen receptor-regulated growth of breast cancer cells. Cancer Res. 2005, 65, 1384-1393. [CrossRef]

214. Dadakhujaev, S.; Salazar-Arcila, C.; Netherton, S.J.; Chandhoke, A.S.; Singla, A.K.; Jirik, F.R.; Bonni, S. A novel role for the SUMO E3 ligase PIAS1 in cancer metastasis. Oncoscience 2014, 1, 229-240. [CrossRef] [PubMed] 
215. Carracedo, A.; Weiss, D.; Leliaert, A.K.; Bhasin, M.; De Boer, V.C.J.; Laurent, G.; Adams, A.C.; Sundvall, M.; Song, S.J.; Ito, K.; et al. A metabolic prosurvival role for PML in breast cancer. J. Clin. Investig. 2012, 122, 3088-3100. [CrossRef] [PubMed]

216. Wang, Z.; Jin, J.; Zhang, J.; Wang, L.; Cao, J. Depletion of SENP1 suppresses the proliferation and invasion of triple-negative breast cancer cells. Oncol. Rep. 2016, 36, 2071-2078. [CrossRef] [PubMed]

217. Kotaja, N.; Aittomäki, S.; Silvennoinen, O.; Palvimo, J.J.; Jänne, O.A. ARIP3 (Androgen Receptor-Interacting Protein 3) and Other PIAS (Protein Inhibitor of Activated STAT) Proteins Differ in Their Ability to Modulate Steroid Receptor-Dependent Transcriptional Activation. Mol. Endocrinol. 2000, 14, 1986-2000. [CrossRef]

218. Gross, M.; Liu, B.; Tan, J.A.; French, F.S.; Carey, M.; Shuai, K. Distinct effects of PIAS proteins on androgen-mediated gene activation in prostate cancer cells. Oncogene 2001, 20, 3880-3887. [CrossRef]

219. Hoefer, J.; Schfer, G.; Klocker, H.; Erb, H.H.H.; Mills, I.G.; Hengst, L.; Puhr, M.; Culig, Z. PIAS1 is increased in human prostate cancer and enhances proliferation through inhibition of p21. Am. J. Pathol. 2012, 180, 2097-2107. [CrossRef]

220. Junicho, A.; Matsuda, T.; Yamamoto, T.; Kishi, H.; Korkmaz, K.; Saatcioglu, F.; Fuse, H.; Muraguchi, A. Protein inhibitor of activated STAT3 regulates androgen receptor signaling in prostate carcinoma cells. Biochem. Biophys. Res. Commun. 2000, 278, 9-13. [CrossRef] [PubMed]

221. Nishida, T.; Yasuda, H. PIAS1 and PIASx $\alpha$ function as SUMO-E3 ligases toward androgen receptor and repress androgen receptor-dependent transcription. J. Biol. Chem. 2002, 277, 41311-41317. [CrossRef] [PubMed]

222. Toropainen, S.; Malinen, M.; Kaikkonen, S.; Rytinki, M.; Jääskeläinen, T.; Sahu, B.; Jänne, O.A.; Palvimo, J.J. SUMO ligase PIAS1 functions as a target gene selective androgen receptor coregulator on prostate cancer cell chromatin. Nucleic Acids Res. 2015, 43, 848-861. [CrossRef]

223. Puhr, M.; Hoefer, J.; Eigentler, A.; Dietrich, D.; Van Leenders, G.; Uhl, B.; Hoogland, M.; Handle, F.; Schlick, B.; Neuwirt, H.; et al. PIAS1 is a determinant of poor survival and acts as a positive feedback regulator of AR signaling through enhanced AR stabilization in prostate cancer. Oncogene 2016, 35, 2322-2332. [CrossRef]

224. Liao, Z.; Lutz, J.; Nevalainen, M.T. Transcription factor Stat5a/b as a therapeutic target protein for prostate cancer. Int. J. Biochem. Cell Biol. 2010, 42, 186-192. [CrossRef] [PubMed]

225. Li, H.; Ahonen, T.J.; Alanen, K.; Xie, J.; LeBaron, M.J.; Pretlow, T.G.; Ealley, E.L.; Zhang, Y.; Nurmi, M.; Singh, B.; et al. Activation of signal transducer and activator of transcription 5 in human prostate cancer is associated with high histological grade. Cancer Res. 2004, 64, 4774-4782. [CrossRef] [PubMed]

226. Van Nguyen, T.; Angkasekwinai, P.; Dou, H.; Lin, F.M.; Lu, L.S.; Cheng, J.; Chin, Y.E.; Dong, C.; Yeh, E.T.H. SUMO-Specific Protease 1 Is Critical for Early Lymphoid Development through Regulation of STAT5 Activation. Mol. Cell 2012, 45, $210-221$. [CrossRef] [PubMed]

227. Dagvadorj, A.; Tan, S.H.; Liao, Z.; Xie, J.; Nurmi, M.; Alanen, K.; Rui, H.; Mirtti, T.; Nevalainen, M.T. N-terminal truncation of Stat5a/b circumvents PIAS3-mediated transcriptional inhibition of Stat5 in prostate cancer cells. Int. J. Biochem. Cell Biol. 2010, 42, 2037-2046. [CrossRef]

228. Poukka, H.; Karvonen, U.; Jänne, O.A.; Palvimo, J.J. Covalent modification of the androgen receptor by small ubiquitin-like modifier 1 (SUMO-1). Proc. Natl. Acad. Sci. USA 2000, 97, 14145-14150. [CrossRef]

229. Zheng, Z.; Cai, C.; Omwancha, J.; Chen, S.Y.; Baslan, T.; Shemshedini, L. SUMO-3 enhances androgen receptor transcriptional activity through a sumoylation-independent mechanism in prostate cancer cells. J. Biol. Chem. 2006, 281, 4002-4012. [CrossRef]

230. Kaikkonen, S.; Jääskeläinen, T.; Karvonen, U.; Rytinki, M.M.; Makkonen, H.; Gioeli, D.; Paschal, B.M.; Palvimo, J.J. SUMO-specific protease 1 (SENP1) reverses the hormone-augmented SUMOylation of androgen receptor and modulates gene responses in prostate cancer cells. Mol. Endocrinol. 2009, 23, 292-307. [CrossRef]

231. Cheng, J.; Bawa, T.; Lee, P.; Gong, L.; Yeh, E.T.H. Role of Desumoylation in the Development of Prostate Cancer. Neoplasia 2006, 8 , 667-676. [CrossRef]

232. Bawa-Khalfe, T.; Cheng, J.; Wang, Z.; Yeh, E.T.H. Induction of the SUMO-specific protease 1 transcription by the androgen receptor in prostate cancer cells. J. Biol. Chem. 2007, 282, 37341-37349. [CrossRef]

233. Cheng, J.; Wang, D.; Wang, Z.; Yeh, E.T.H. SENP1 Enhances Androgen Receptor-Dependent Transcription through Desumoylation of Histone Deacetylase 1. Mol. Cell. Biol. 2004, 24, 6021-6028. [CrossRef]

234. Yang, Y.; Tse, A.K.W.; Li, P.; Ma, Q.; Xiang, S.; Nicosia, S.V.; Seto, E.; Zhang, X.; Bai, W. Inhibition of androgen receptor activity by histone deacetylase 4 through receptor SUMOylation. Oncogene 2011, 30, 2207-2218. [CrossRef]

235. Kim, J.H.; Choi, H.J.; Kim, B.; Kim, M.H.; Lee, J.M.; Kim, I.S.; Lee, M.H.; Choi, S.J.; Kim, K.I.; Kim, S.I.; et al. Roles of sumoylation of a reptin chromatin-remodelling complex in cancer metastasis. Nat. Cell Biol. 2006, 8, 631-639. [CrossRef]

236. Huang, W.; He, T.; Chai, C.; Yang, Y.; Zheng, Y.; Zhou, P.; Qiao, X.; Zhang, B.; Liu, Z.; Wang, J.; et al. Triptolide inhibits the proliferation of prostate cancer cells and down-regulates SUMO-specific protease 1 expression. PLoS ONE 2012, 7, e37693. [CrossRef]

237. Wu, J.; Lei, H.; Zhang, J.; Chen, X.; Tang, C.; Wang, W.; Xu, H.; Xiao, W.; Gu, W.; Wu, Y.L. Momordin Ic, a new natural SENP1 inhibitor, inhibits prostate cancer cell proliferation. Oncotarget 2016, 7, 58995-59005. [CrossRef] [PubMed]

238. Bawa-Khalfe, T.; Yang, F.M.; Ritho, J.; Lin, H.K.; Cheng, J.; Yeh, E.T.H. SENP1 regulates PTEN stability to dictate prostate cancer development. Oncotarget 2017, 8, 17651-17664. [CrossRef] [PubMed]

239. Shangguan, X.; He, J.; Ma, Z.; Zhang, W.; Ji, Y.; Shen, K.; Yue, Z.; Li, W.; Xin, Z.; Zheng, Q.; et al. SUMOylation controls the binding of hexokinase 2 to mitochondria and protects against prostate cancer tumorigenesis. Nat. Commun. 2021, 12, 1812. [CrossRef] 
240. Wen, D.; Xu, Z.; Xia, L.; Liu, X.; Tu, Y.; Lei, H.; Wang, W.; Wang, T.; Song, L.; Ma, C.; et al. Important role of SUMOylation of spliceosome factors in prostate cancer cells. J. Proteome Res. 2014, 13, 3571-3582. [CrossRef]

241. Ashikari, D.; Takayama, K.; Tanaka, T.; Suzuki, Y.; Obinata, D.; Fujimura, T.; Urano, T.; Takahashi, S.; Inoue, S. Androgen induces G3BP2 and SUMO-mediated p53 nuclear export in prostate cancer. Oncogene 2017, 36, 6272-6281. [CrossRef]

242. Jaakkola, P.; Mole, D.R.; Tian, Y.M.; Wilson, M.I.; Gielbert, J.; Gaskell, S.J.; Von Kriegsheim, A.; Hebestreit, H.F.; Mukherji, M.; Schofield, C.J.; et al. Targeting of HIF- $\alpha$ to the von Hippel-Lindau ubiquitylation complex by $\mathrm{O}_{2}$-regulated prolyl hydroxylation. Science 2001, 292, 468-472. [CrossRef] [PubMed]

243. Ivan, M.; Kondo, K.; Yang, H.; Kim, W.; Valiando, J.; Ohh, M.; Salic, A.; Asara, J.M.; Lane, W.S.; Kaelin, J. HIF $\alpha$ targeted for VHL-mediated destruction by proline hydroxylation: Implications for $\mathrm{O}_{2}$ sensing. Science 2001, 292, 464-468. [CrossRef]

244. Van Hagen, M.; Overmeer, R.M.; Abolvardi, S.S.; Vertegaal, A.C.O. RNF4 and VHL regulate the proteasomal degradation of SUMO-conjugated Hypoxia-Inducible Factor-2 $\alpha$. Nucleic Acids Res. 2009, 38, 1922-1931. [CrossRef]

245. Dong, B.; Gao, Y.; Kang, X.; Gao, H.; Zhang, J.; Guo, H.; You, M.J.; Xue, W.; Cheng, J.; Huang, Y. SENP1 promotes proliferation of clear cell renal cell carcinoma through activation of glycolysis. Oncotarget 2016, 7, 80435-80449. [CrossRef]

246. Gerez, J.; Tedesco, L.; Bonfiglio, J.J.; Fuertes, M.; Barontini, M.; Silberstein, S.; Wu, Y.; Renner, U.; Paéz-Pereda, M.; Holsboer, F.; et al. RSUME inhibits VHL and regulates its tumor suppressor function. Oncogene 2015, 34, 4855-4866. [CrossRef]

247. Tedesco, L.; Elguero, B.; Pacin, D.G.; Senin, S.; Pollak, C.; Garcia Marchiñena, P.A.; Jurado, A.M.; Isola, M.; Labanca, M.J.; Palazzo, M.; et al. von Hippel-Lindau mutants in renal cell carcinoma are regulated by increased expression of RSUME. Cell Death Dis. 2019, 10, 266. [CrossRef]

248. Kadaré, G.; Toutant, M.; Formstecher, E.; Corvol, J.C.; Carnaud, M.; Boutterin, M.C.; Girault, J.A. PIAS1-mediated Sumoylation of Focal Adhesion Kinase Activates Its Autophosphorylation. J. Biol. Chem. 2003, 278, 47434-47440. [CrossRef]

249. Hung, P.F.; Hong, T.M.; Chang, C.C.; Hung, C.L.; Hsu, Y.L.; Chang, Y.L.; Wu, C.T.; Chang, G.C.; Chan, N.L.; Yu, S.L.; et al Hypoxia-induced Slug SUMOylation enhances lung cancer metastasis. J. Exp. Clin. Cancer Res. 2019, 38, 5. [CrossRef]

250. Chung, C.D.; Liao, J.; Liu, B.; Rao, X.; Jay, P.; Berta, P.; Shuai, K. Specific Inhibition of Stat3 Signal Transduction by PIAS3. Science 1997, 278, 1803-1805. [CrossRef] [PubMed]

251. Ogata, Y.; Osaki, T.; Naka, T.; Iwahori, K.; Furukawa, M.; Nagatomo, I.; Kijima, T.; Kumagai, T.; Yoshida, M.; Tachibana, I.; et al. Overexpression of PIAS3 suppresses cell growth and restores the drug sensitivity of human lung cancer cells in association with PI3-K/Akt inactivation. Neoplasia 2006, 8, 817-825. [CrossRef] [PubMed]

252. Kluge, A.; Dabir, S.; Kern, J.; Nethery, D.; Halmos, B.; Ma, P.; Dowlati, A. Cooperative interaction between protein inhibitor of activated signal transducer and activator of transcription-3 with epidermal growth factor receptor blockade in lung cancer. Int. J. Cancer 2009, 125, 1728-1734. [CrossRef] [PubMed]

253. Dabir, S.; Kluge, A.; McColl, K.; Liu, Y.; Lam, M.; Halmos, B.; Wildey, G.; Dowlati, A. PIAS3 activates the intrinsic apoptotic pathway in non-small cell lung cancer cells independent of p53 status. Int. J. Cancer 2014, 134, 1045-1054. [CrossRef] [PubMed]

254. Abbas, R.; McColl, K.S.; Kresak, A.; Yang, M.; Chen, Y.; Fu, P.; Wildey, G.; Dowlati, A. PIAS3 expression in squamous cell lung cancer is low and predicts overall survival. Cancer Med. 2015, 4, 325-332. [CrossRef]

255. Cui, C.P.; Wong, C.C.L.; Kai, A.K.L.; Ho, D.W.H.; Lau, E.Y.T.; Tsui, Y.M.; Chan, L.K.; Cheung, T.T.; Chok, K.S.H.; Chan, A.C.Y.; et al. SENP1 promotes hypoxia-induced cancer stemness by HIF-1 $\alpha$ deSUMOylation and SENP1/HIF- $1 \alpha$ positive feedback loop. Gut 2017, 66, 2149-2159. [CrossRef]

256. Tao, Y.; Li, R.; Shen, C.; Li, J.; Zhang, Q.; Ma, Z.; Wang, F.; Wang, Z. SENP1 is a crucial promotor for hepatocellular carcinoma through deSUMOylation of UBE2T. Aging 2020, 12, 1563-1576. [CrossRef]

257. Deng, R.; Zhao, X.; Qu, Y.Y.; Chen, C.; Zhu, C.; Zhang, H.; Yuan, H.; Jin, H.; Liu, X.; Wang, Y.; et al. Shp2 SUMOylation promotes ERK activation and hepatocellular carcinoma development. Oncotarget 2015, 6, 9355-9369. [CrossRef]

258. Yang, W.; Wang, L.; Roehn, G.; Pearlstein, R.D.; Ali-Osman, F.; Pan, H.; Goldbrunner, R.; Krantz, M.; Harms, C.; Paschen, W. Small ubiquitin-like modifier 1-3 is activated in human astrocytic brain tumors and is required for glioblastoma cell survival. Cancer Sci. 2013, 104, 70-77. [CrossRef] [PubMed]

259. Bellail, A.C.; Olson, J.J.; Hao, C. SUMO1 modification stabilizes CDK6 protein and drives the cell cycle and glioblastoma progression. Nat. Commun. 2014, 5, 4234. [CrossRef] [PubMed]

260. Bernstock, J.D.; Ye, D.; Gessler, F.A.; Lee, Y.J.; Peruzzotti-Jametti, L.; Baumgarten, P.; Johnson, K.R.; Maric, D.; Yang, W.; Kögel, D.; et al. Topotecan is a potent inhibitor of SUMOylation in glioblastoma multiforme and alters both cellular replication and metabolic programming. Sci. Rep. 2017, 7, 7425. [CrossRef]

261. Zhang, A.; Tao, W.; Zhai, K.; Fang, X.; Huang, Z.; Yu, J.S.; Sloan, A.E.; Rich, J.N.; Zhou, W.; Bao, S. Protein sumoylation with SUMO1 promoted by Pin1 in glioma stem cells augments glioblastoma malignancy. Neuro-Oncology 2020, 22, $1809-1821$. [CrossRef] [PubMed]

262. Kroonen, J.S.; Vertegaal, A.C.O. Targeting SUMO Signaling to Wrestle Cancer. Trends Cancer 2021, 7, 496-510. [CrossRef]

263. Fukuda, I.; Ito, A.; Hirai, G.; Nishimura, S.; Kawasaki, H.; Saitoh, H.; Kimura, K.I.; Sodeoka, M.; Yoshida, M. Ginkgolic Acid Inhibits Protein SUMOylation by Blocking Formation of the E1-SUMO Intermediate. Chem. Biol. 2009, 16, 133-140. [CrossRef]

264. Fukuda, I.; Ito, A.; Uramoto, M.; Saitoh, H.; Kawasaki, H.; Osada, H.; Yoshida, M. Kerriamycin B inhibits protein SUMOylation. J. Antibiot. 2009, 62, 221-224. [CrossRef] 
265. Takemoto, M.; Kawamura, Y.; Hirohama, M.; Yamaguchi, Y.; Handa, H.; Saitoh, H.; Nakao, Y.; Kawada, M.; Khalid, K.; Koshino, H.; et al. Inhibition of protein SUMOylation by davidiin, an ellagitannin from Davidia involucrata. J. Antibiot. 2014, 67, 335-338. [CrossRef]

266. Suzawa, M.; Miranda, D.A.; Ramos, K.A.; Ang, K.K.H.; Faivre, E.J.; Wilson, C.G.; Caboni, L.; Arkin, M.R.; Kim, Y.S.; Fletterick, R.J.; et al. A gene-expression screen identifies a non-toxic sumoylation inhibitor that mimics SUMO-less human LRH-1 in liver. eLife 2015, 4. [CrossRef]

267. Kumar, A.; Ito, A.; Hirohama, M.; Yoshida, M.; Zhang, K.Y.J. Identification of quinazolinyloxy biaryl urea as a new class of SUMO activating enzyme 1 inhibitors. Bioorg. Med. Chem. Lett. 2013, 23, 5145-5149. [CrossRef] [PubMed]

268. Kumar, A.; Ito, A.; Hirohama, M.; Yoshida, M.; Zhang, K.Y.J. Identification of sumoylation activating enzyme 1 inhibitors by structure-based virtual screening. J. Chem. Inf. Model. 2013, 53, 809-820. [CrossRef]

269. Kumar, A.; Ito, A.; Hirohama, M.; Yoshida, M.; Zhang, K.Y.J. Identification of new SUMO activating enzyme 1 inhibitors using virtual screening and scaffold hopping. Bioorg. Med. Chem. Lett. 2016, 26, 1218-1223. [CrossRef]

270. He, X.; Riceberg, J.; Soucy, T.; Koenig, E.; Minissale, J.; Gallery, M.; Bernard, H.; Yang, X.; Liao, H.; Rabino, C.; et al. Probing the roles of SUMOylation in cancer cell biology by using a selective SAE inhibitor. Nat. Chem. Biol. 2017, 13, 1164-1171. [CrossRef]

271. Lv, Z.; Yuan, L.; Atkison, J.H.; Williams, K.M.; Vega, R.; Sessions, E.H.; Divlianska, D.B.; Davies, C.; Chen, Y.; Olsen, S.K. Molecular mechanism of a covalent allosteric inhibitor of SUMO E1 activating enzyme. Nat. Commun. 2018, 9, 5145. [CrossRef]

272. Li, Y.J.; Du, L.; Wang, J.; Vega, R.; Lee, T.D.; Miao, Y.; Aldana-Masangkay, G.; Samuels, E.R.; Li, B.; Ouyang, S.X.; et al. Allosteric Inhibition of Ubiquitin-like Modifications by a Class of Inhibitor of SUMO-Activating Enzyme. Cell Chem. Biol. 2019, 26, 278-288.e6. [CrossRef] [PubMed]

273. Biederstädt, A.; Hassan, Z.; Schneeweis, C.; Schick, M.; Schneider, L.; Muckenhuber, A.; Hong, Y.; Siegers, G.; Nilsson, L.; Wirth, M.; et al. SUMO pathway inhibition targets an aggressive pancreatic cancer subtype. Gut 2020, 69, 1472-1482. [CrossRef]

274. Brackett, C.M.; García-Casas, A.; Castillo-Lluva, S.; Blagg, B.S.J. Synthesis and Evaluation of Ginkgolic Acid Derivatives as SUMOylation Inhibitors. ACS Med. Chem. Lett. 2020, 11, 2221-2226. [CrossRef] [PubMed]

275. Langston, S.P.; Grossman, S.; England, D.; Afroze, R.; Bence, N.; Bowman, D.; Bump, N.; Chau, R.; Chuang, B.C.; Claiborne, C.; et al. Discovery of TAK-981, a First-in-Class Inhibitor of SUMO-Activating Enzyme for the Treatment of Cancer. J. Med. Chem. 2021, 64, 2501-2520. [CrossRef]

276. Khattar, M.; Song, K.; Grossman, S.; Xega, K.; He, X.; Idamakanti, N.; Huszar, D. Abstract 3252: TAK-981: A first in class SUMO inhibitor in Phase 1 trials that promotes dendritic cell activation, antigen-presentation, and T cell priming. Cancer Res. 2019, 79, 3252. [CrossRef]

277. Nakamura, A.; Grossman, S.; Song, K.; Idamakanti, N.; Shapiro, G.; Huszar, D. Abstract 1523: Inhibition of SUMOylation by TAK-981 induces antitumor innate immune responses by modulating macrophage and NK cell function through Type I IFN pathway activation. Cancer Res. 2019, 79, 1523. [CrossRef]

278. Nakamura, A.; Song, K.; Grossman, S.; Xega, K.; Zhang, Y.; Berger, A.; Berger, A.; Shapiro, G.; Huszar, D. Abstract 552: SUMOylation inhibitor TAK-981 activates NK cells and macrophages via Type I interferon signaling and shows synergistic activity in combination with rituximab and daratumumab in preclinical models. J. Immunother. Cancer 2020, 8, A588. [CrossRef]

279. Hirohama, M.; Kumar, A.; Fukuda, I.; Matsuoka, S.; Igarashi, Y.; Saitoh, H.; Takagi, M.; Shin-Ya, K.; Honda, K.; Kondoh, Y.; et al. Spectomycin B1 as a novel sumoylation inhibitor that directly binds to SUMO E2. ACS Chem. Biol. 2013, 8, 2635-2642. [CrossRef]

280. Brandt, M.; Szewczuk, L.M.; Zhang, H.; Hong, X.; McCormick, P.M.; Lewis, T.S.; Graham, T.I.; Hung, S.T.; Harper-Jones, A.D.; Kerrigan, J.J.; et al. Development of a High-Throughput Screen to Detect Inhibitors of TRPS1 Sumoylation. Assay Drug Dev. Technol. 2013, 11, 308-325. [CrossRef]

281. Kim, Y.S.; Nagy, K.; Keyser, S.; Schneekloth, J.S. An electrophoretic mobility shift assay identifies a mechanistically unique inhibitor of protein sumoylation. Chem. Biol. 2013, 20, 604-613. [CrossRef] [PubMed]

282. Zlotkowski, K.; Hewitt, W.M.; Sinniah, R.S.; Tropea, J.E.; Needle, D.; Lountos, G.T.; Barchi, J.J.; Waugh, D.S.; Schneekloth, J.S. A Small-Molecule Microarray Approach for the Identification of E2 Enzyme Inhibitors in Ubiquitin-Like Conjugation Pathways. SLAS Discov. 2017, 22, 760-766. [CrossRef]

283. Wiechmann, S.; Gärtner, A.; Kniss, A.; Stengl, A.; Behrends, C.; Rogov, V.V.; Rodriguez, M.S.; Dötsch, V.; Müller, S.; Ernst, A. Site-specific inhibition of the small ubiquitin-like modifier (SUMO)-conjugating enzyme Ubc9 selectively impairs SUMO chain formation. J. Biol. Chem. 2017, 292, 15340-15351. [CrossRef] [PubMed]

284. Choi, B.H.; Philips, M.R.; Chen, Y.; Lu, L.; Dai, W. K-Ras Lys-42 is crucial for its signaling, cell migration, and invasion. J. Biol. Chem. 2018, 293, 17574-17581. [CrossRef]

285. Huang, X.; Tao, Y.; Gao, J.; Zhou, X.; Tang, S.; Deng, C.; Lai, Z.; Lin, X.; Wang, Q.; Li, T. UBC9 coordinates inflammation affecting development of bladder cancer. Sci. Rep. 2020, 10, 20670. [CrossRef]

286. Tokarz, P.; Woźniak, K. SENP Proteases as Potential Targets for Cancer Therapy. Cancers 2021, 13, 2059. [CrossRef] [PubMed]

287. Qiao, Z.; Wang, W.; Wang, L.; Wen, D.; Zhao, Y.; Wang, Q.; Meng, Q.; Chen, G.; Wu, Y.; Zhou, H. Design, synthesis, and biological evaluation of benzodiazepine-based SUMO-specific protease 1 inhibitors. Bioorg. Med. Chem. Lett. 2011, 21, 6389-6392. [CrossRef]

288. Chen, Y.; Wen, D.; Huang, Z.; Huang, M.; Luo, Y.; Liu, B.; Lu, H.; Wu, Y.; Peng, Y.; Zhang, J. 2-(4-Chlorophenyl)-2-oxoethyl 4-benzamidobenzoate derivatives, a novel class of SENP1 inhibitors: Virtual screening, synthesis and biological evaluation. Bioorg. Med. Chem. Lett. 2012, 22, 6867-6870. [CrossRef] [PubMed] 
289. Uno, M.; Koma, Y.; Ban, H.S.; Nakamura, H. Discovery of 1-[4-(N-benzylamino)phenyl]-3-phenylurea derivatives as non-peptidic selective SUMO-sentrin specific protease (SENP)1 inhibitors. Bioorg. Med. Chem. Lett. 2012, 22, 5169-5173. [CrossRef] [PubMed]

290. Zhao, Y.; Wang, Z.; Zhang, J.; Zhou, H. Identification of SENP1 inhibitors through in silico screening and rational drug design. Eur. J. Med. Chem. 2016, 122, 178-184. [CrossRef]

291. Lindenmann, U.; Brand, M.; Gall, F.; Frasson, D.; Hunziker, L.; Kroslakova, I.; Sievers, M.; Riedl, R. Discovery of a Class of Potent and Selective Non-competitive Sentrin-Specific Protease 1 Inhibitors. ChemMedChem 2020, 15, 675-679. [CrossRef]

292. Kumar, A.; Ito, A.; Takemoto, M.; Yoshida, M.; Zhang, K.Y.J. Identification of 1,2,5-oxadiazoles as a new class of SENP2 inhibitors using structure based virtual screening. J. Chem. Inf. Model. 2014, 54, 870-880. [CrossRef]

293. Bernstock, J.D.; Ye, D.; Smith, J.A.; Lee, Y.J.; Gessler, F.A.; Yasgar, A.; Kouznetsova, J.; Jadhav, A.; Wang, Z.; Pluchino, S.; et al. Quantitative high-throughput screening identifies cytoprotective molecules that enhance SUMO conjugation via the inhibition of SUMO-specific protease (SENP)2. FASEB J. 2018, 32, 1677-1691. [CrossRef] [PubMed]

294. Wang, D.P.; Liu, K.J.; Kasper, G.; Lin, Q.; Hai, J. Inhibition of SENP3 by URB597 ameliorates neurovascular unit dysfunction in rats with chronic cerebral hypoperfusion. Biomed. Pharmacother. 2017, 91, 872-879. [CrossRef] [PubMed]

295. Albrow, V.E.; Ponder, E.L.; Fasci, D.; Békés, M.; Deu, E.; Salvesen, G.S.; Bogyo, M. Development of small molecule inhibitors and probes of human SUMO deconjugating proteases. Chem. Biol. 2011, 18, 722-732. [CrossRef] [PubMed]

296. Ponder, E.L.; Albrow, V.E.; Leader, B.A.; Békés, M.; Mikolajczyk, J.; Fonović, U.P.; Shen, A.; Drag, M.; Xiao, J.; Deu, E.; et al. Functional characterization of a SUMO deconjugating protease of Plasmodium falciparum using newly identified small molecule inhibitors. Chem. Biol. 2011, 18, 711-721. [CrossRef]

297. Dobrotă, C.; Fasci, D.; Hădade, N.D.; Roiban, G.-D.; Pop, C.; Meier, V.M.; Dumitru, I.; Matache, M.; Salvesen, G.S.; Funeriu, D.P. Glycine Fluoromethylketones as SENP-Specific Activity Based Probes. ChemBioChem 2012, 13, 80-84. [CrossRef]

298. Xie, W.; Wang, Z.; Zhang, J.; Wang, L.; Zhao, Y.; Zhou, H. Development and evaluation of a highly reliable assay for SUMO-specific protease inhibitors. Bioorg. Med. Chem. Lett. 2016, 26, 2124-2128. [CrossRef] [PubMed]

299. Ambaye, N.; Chen, C.H.; Khanna, S.; Li, Y.J.; Chen, Y. Streptonigrin Inhibits SENP1 and Reduces the Protein Level of HypoxiaInducible Factor $1 \alpha(\mathrm{HIF} 1 \alpha)$ in Cells. Biochemistry 2018, 57, 1807-1813. [CrossRef] [PubMed]

300. Wang, Z.; Liu, Y.; Zhang, J.; Ullah, S.; Kang, N.; Zhao, Y.; Zhou, H. Benzothiophene-2-carboxamide derivatives as SENPs inhibitors with selectivity within SENPs family. Eur. J. Med. Chem. 2020, 204, 112553. [CrossRef]

301. Madu, I.G.; Namanja, A.T.; Su, Y.; Wong, S.; Li, Y.J.; Chen, Y. Identification and characterization of a new chemotype of noncovalent SENP inhibitors. ACS Chem. Biol. 2013, 8, 1435-1441. [CrossRef] [PubMed]

302. Lu, X.; Olsen, S.K.; Capili, A.D.; Cisar, J.S.; Lima, C.D.; Tan, D.S. Designed semisynthetic protein inhibitors of Ub/Ubl E1 activating enzymes. J. Am. Chem. Soc. 2010, 132, 1748-1749. [CrossRef]

303. Puhr, M.; Hoefer, J.; Neuwirt, H.; Eder, I.E.; Kern, J.; Schäfer, G.; Geley, S.; Heidegger, I.; Klocker, H.; Culig, Z. PIAS1 is a crucial factor for prostate cancer cell survival and a valid target in docetaxel resistant cells. Oncotarget 2014, 5, 12043-12056. [CrossRef] [PubMed]

304. Wu, Y.C.; Ling, T.Y.; Lu, S.H.; Kuo, H.C.; Ho, H.N.; Yeh, S.D.; Shen, C.N.; Huang, Y.H. Chemotherapeutic sensitivity of testicular germ cell tumors under hypoxic conditions is negatively regulated by SENP1-controlled sumoylation of OCT4. Cancer Res. 2012, 72, 4963-4973. [CrossRef]

305. Li, J.; Wu, R.; Yung, M.M.H.; Sun, J.; Li, Z.; Yang, H.; Zhang, Y.; Liu, S.S.; Cheung, A.N.Y.; Ngan, H.Y.S.; et al. SENP1-mediated deSUMOylation of JAK2 regulates its kinase activity and platinum drug resistance. Cell Death Dis. 2021, 12, 341. [CrossRef] [PubMed]

306. Modell, A.E.; Lai, S.; Nguyen, T.M.; Choudhary, A. Bifunctional modalities for repurposing protein function. Cell Chem. Biol. 2021, 28, 1081-1089. [CrossRef] 